\title{
Effects of Integrated Nutrient Management on Potato (Solanum tuberosum L.) Growth, Yield and Yield Components at Haramaya Watershed, Eastern Ethiopia
}

\author{
Abdulaziz Mohammed', Muktar Mohammed1, Niguse Dechasa' ${ }^{2}$, Fuad Abduselam ${ }^{3 *}$ \\ ${ }^{1}$ School of Natural Resources Management and Environmental Science, College of Agriculture and Environmental Science, \\ Oda Bultum University, Chiro, Ethiopia \\ ${ }^{2}$ Collage of Agriculture and Environmental Sciences, Haramaya University, Dire Dawa, Ethiopia \\ ${ }^{3}$ Fadis Agricultural Research Center, Oromia Agricultural Research Institute, Harar, Ethiopia \\ Email: *nasib2831@gmail.com
}

How to cite this paper: Mohammed, A., Mohammed, M., Dechasa, N. and Abduselam, F. (2018) Effects of Integrated Nutrient Management on Potato (Solanum tuberosum L.) Growth, Yield and Yield Components at Haramaya Watershed, Eastern Ethiopia. Open Access Library Journal, 5: e3974. https://doi.org/10.4236/oalib.1103974

Received: September 26, 2017

Accepted: March 27, 2018

Published: March 30, 2018

Copyright $\odot 2018$ by authors and Open Access Library Inc.

This work is licensed under the Creative Commons Attribution International License (CC BY 4.0).

http://creativecommons.org/licenses/by/4.0/

\begin{abstract}
Potato is an important food security and cash crop in eastern Hararghe Zone. However, the productivity of the crop is constrained by low soil fertility and poor fertilizer management practices. Therefore, a field experiment was conducted at Haramaya watershed in Haramaya District, Eastern Ethiopia; during the 2014 off season using irrigation. The main objective of the study was to assess the effects of integrated nutrient management on potato growth, yield and yield components. The treatments were three rates of farmyard manure $\left(0,5,10, \mathrm{t} \mathrm{ha}^{-1}\right)$, three rates of $\mathrm{N}\left(0,55.5,111 \mathrm{~kg} \mathrm{~N} \mathrm{ha}^{-1}\right)$, and three rates of phosphorus $\left(0,46,92 \mathrm{~kg} \mathrm{P}_{2} \mathrm{O}_{5} \mathrm{ha}^{-1}\right)$. The experiment was laid out as a randomized complete block design in (RCBD) in a factorial arrangement with three replications. The results showed that the effect of integrated use of organic and inorganic fertilizer had significant influence on plant height, above ground biomass, day to maturity, total tuber yield, average tuber number/hill, average tuber mass/hill, marketable tuber number and tuber dry matter yield. The highest marketable tuber yields of $38.65 \mathrm{t} \mathrm{ha}^{-1}$ followed by $36.24 \mathrm{t} \mathrm{ha}^{-1}$ were obtained in response to a combined application of farm yard manure, $\mathrm{N}$ and $\mathrm{P}$ at the rates of $10 \mathrm{t} \mathrm{FYM} \mathrm{ha}{ }^{-1}+111 \mathrm{~kg} \mathrm{~N} \mathrm{ha}^{-1}+92 \mathrm{~kg} \mathrm{P}_{2} \mathrm{O}_{5} \mathrm{ha}^{-1}$ and 10 ton FYM $\mathrm{ha}^{-1}+111 \mathrm{~kg} \mathrm{~N} \mathrm{ha}^{-1}+46 \mathrm{~kg}_{2} \mathrm{O}_{5} \mathrm{ha}^{-1}$, respectively. The marketable and total tuber yields were positively and significantly correlated with all growth and yield components studied but negatively and significantly correlated with the number of main stem/hill, unmarketable tuber yield. In conclusion, application of farm yard manure with, $\mathrm{N}$ and $\mathrm{P}$ not only significantly improved prod-
\end{abstract}


uctivity, but also profitability of the crop.

\section{Subject Areas}

Agricultural Science

\section{Keywords}

FYM, Inorganic Fertilizer, Marketable Tuber Yield

\section{Introduction}

The annual production of potato in Ethiopia is low (about 784,993.4 tons) and the national average yield is 11.76 tons $\mathrm{ha}^{-1}$ [1], which is very low compared to the world's average yield of 16.4 tons $\mathrm{ha}^{-1}$ and that of other potato producing countries of the world such as New Zealand (50 tons ha ${ }^{-1}$ ), Netherlands (44.7 tons $\mathrm{ha}^{-1}$ ), USA (44.6 tons ha ${ }^{-1}$ ) [2]. There are several causes for the low yield of the crop in the country among which depleted soil fertility, poor agronomic practices, and diseases and pests are the main [3]. Soil nutrients are being depleted in Ethiopia because of, soil erosion, leaching, removal by crops, low external input of nutrients, as well as absence of crop residue incorporation for restoration of soil fertility [4]. [5] stated that, declining soil fertility is one of the most significant constraints to increased food production in Ethiopia. The essential plant nutrients, $\mathrm{N}$ and $\mathrm{P}$ are of the deficient nutrients in many soil of Ethiopia [6]. Whereas, most cultivated soils of Ethiopia are poor in their organic matter (OM) content due to low amount of organic materials applied to the soil and complete removal of the biomass from the field [7].

Blanket rates of nitrogen and phosphorus in the form of Urea and DAP (165 $\mathrm{kg}$ urea and $195 \mathrm{~kg} \mathrm{DAP} / \mathrm{ha}$ ), which amount to $110 \mathrm{~kg} \mathrm{~N} \mathrm{ha}^{-1}$ and $90 \mathrm{~kg} \mathrm{P}_{2} \mathrm{O}_{5} / \mathrm{ha}$, respectively, have been formulated to be used as recommended rates for potato production on Nitosol of Holeta, in the central highlands of Ethiopia [8]. The same rates of the mineral fertilizers have been blanket-used for potato production across most parts of the country regardless of soil and environmental conditions for more than 20 years. Current blanket recommendation of $111 \mathrm{~N} \mathrm{~kg}$ $\mathrm{ha}^{-1}$ was recommended by [9] for the variety Bubu in Eastern Hareghe of Haramaya district. The same recommendation of $111 \mathrm{~N} \mathrm{~kg} \mathrm{ha}^{-1}$ and $92 \mathrm{P}_{2} \mathrm{O}_{5}$ was given by [8] and this recommendation has been used for different researches [10] and potato producers since then.

The integrated nutrient management paradigm acknowledges the need for both organic and inorganic mineral inputs to sustain soil health and crop production due to positive interaction and complementarities between them [11] [12]. It is a strategy that incorporates both organic and inorganic plant nutrients to attain higher crop productivity, prevent soil degradation and thereby help meet future food supply needs. Integrated soil fertility management is applica- 
tion of soil fertility management practices, and the knowledge to adapt these to local conditions, which maximize fertilizer and organic resource use efficiency and crop productivity [13]. Thus, this study was conducted to investigate the effects of integrated nutrient management on growth and yield of potato.

\section{Materials and Methods}

\subsection{Description of the Study Area}

The study was conducted at Haramaya watershed on community farm during the 2014 cropping season in eastern Hararghe Zone in the Oromiya National Regional State (ONRS). The location of the site is about $510 \mathrm{~km}$ far from Addis Ababa $18 \mathrm{~km}$ from Harar town at $09^{\circ} 26^{\prime} \mathrm{N}$ and $42^{\circ} 3^{\prime} \mathrm{E}$ in the easterly direction. The average altitude of the research site is about 2004 meters above sea level. It is found in the semi-arid tropical belt of eastern Hararghe Zone. The rainfall is erratic and uneven in distribution. The site has a bimodal rainfall distribution and is a representative of a sub humid mid-altitude agro-climatic zone. The short rainy season extends from March to April and whereas the long rainy season extends from June to October and the annual rainfall is $790 \mathrm{~mm}$, mean temperature is $16.8^{\circ} \mathrm{C}$ with mean minimum and maximum temperature of $1.4^{\circ} \mathrm{C}$ and $23.4^{\circ} \mathrm{C}$, respectively.

The major surrounding land form is plateau and the experimental site is located at lower slope position. Rain-fed agricultural practices are the common land use types and sometimes the use underground water for vegetables production during drying season. The study was conducted on cultivated land under irrigation around a delineated irrigation farm boundary. The source of irrigation water was pond. The farming practices involve mixed type of cultivation of crop. The major arable crops in the area are sorghum (Sorghum bicolor (L.) Moench), Maize (Zea mays), khat (Catha edulis Forsk) and vegetables. Farmers practice both intercropping and mono-cropping of these crops.

\subsection{Experimental Materials and Design}

The effects of integrated nutrient management (INM) were investigated using potato as a test crop under irrigation. The improved variety named Bubu, which was released by potato improvement program of the Haramaya University in 2006. The variety is well known by farmers in the area for its high yield, late blight rust resistance, and good quality tubers. The fertilizer used for this experiment included urea, which is a source of nitrogen $(46 \% \mathrm{~N})$ and TSP, which is a source of phosphorus $\left(46 \% \mathrm{P}_{2} \mathrm{O}_{5}\right)$. Farmyard manure: Goat manure was used as an organic fertilizer for the trial. The manure was collected from locally available goat dung from the farmers' field. The fresh goat manure was piled and stored for three months before application for decomposition.

The treatments consisted of three rates of nitrogen $\left(0,55.5,111 \mathrm{~kg} \mathrm{~N} \mathrm{ha}^{-1}\right)$, three rates of phosphorus $\left(0,46,92 \mathrm{~kg} \mathrm{P}_{2} \mathrm{O}_{5} \mathrm{ha}^{-1}\right)$, and three rates of farmyard manure $\left(0,5,10 \mathrm{tha}^{-1}\right)$. The experiment was laid out as a randomized complete 
blocking design (RCBD) in a factorial arrangement. Each treatment was replicated three times, and assigned randomly to each plot. Each plot size was $3.75 \mathrm{~m}$ long and $3.0 \mathrm{~m}$ wide, and consisted of five rows, with each row containing 10 plants with a total of 50 plants per plot. Blocks were separated by a distance of 1.5 meters whereas plots were separated by a distance of $1 \mathrm{~m}$.

\subsection{Experimental Procedure}

The experimental field was prepared following the conventional farmers' practices. The field was ploughed by oxen three times before sowing. The sprouted tubers were planted directly in rows with the spacing of $75 \mathrm{~cm}$ between rows and $30 \mathrm{~cm}$ between plants, in January 14, 2014. Urea and TSP were used as sources of $\mathrm{N}$ and P. The whole dose of TSP and half dose of Urea were applied at planting time by side application method and the remaining half dose of urea was applied one month after planting (at tuber initiation stage) using the split application method. Hand weeding was done when required, to keep the plots clean and free from weed competition. Weeding was done three times during the period of experimentation. Two weeks before harvesting, the haulms were cut and the crop was harvested in May 21, 2014 by digging when the soil moisture was optimum. Tubers were harvested from the medium 3 rows by leaving the plants growing in the two border rows and those growing at both ends of each row to avoid border effect and the tuber were harvested using traditional implements.

\subsection{Data Collection and Measurement}

The plants were picked at random from the middle three ridges and dug out. Five plants were selected randomly from the net plot area for recording observations on growth performance and yield related parameters like tuber number per hill and tuber mass per hill data were taken from the whole net plot for tuber yield. Growth parameters recorded were days of emergence, days to maturity, plant height $(\mathrm{cm})$, total leaf area per hill, days to flowering, number of main stem per hill and above ground biomass while yield and yield components parameters collected were average tuber number per hill, average tuber mass per hill, marketable and unmarketable tuber numbers, total tuber number per plot, marketable tuber yield, unmarketable tuber yield and total tuber yield.

Quality Parameters; Tuber Dry Matter Content (\%): Five potato tubers were randomly selected from each plot, chopped into small (1-2 cm cubes), mixed thoroughly, and two fresh sub-samples each weighing $200 \mathrm{~g}$ were taken for drying to a constant weight. Each sub-sample was placed in a paper bag and put in an oven at $70^{\circ} \mathrm{C}$ for 72 hours. Each sub-sample was immediately weighed and the mean recorded as dry weight. Percent dry matter content for each sub-sample was calculated based on the formula described by [14].

$$
\text { Dry matter }(\%)=\frac{\text { Weight of sample after drying }(\mathrm{g})}{\text { Initial weight of sample }(\mathrm{g})} \times 100
$$




\subsection{Statistical Analysis}

Crop data were statistically analyzed by analysis of variance (ANOVA) using the Statistic Analysis System (SAS 2002) software package (version 9.1). To identify the differences between treatments, the treatment means were compared using Duncan's Multiple Range Test (DMRT) at 5\% level of significance.

\section{Results and Discussion}

\subsection{Days to Flowering and Maturity}

The results of the main effects of N, P fertilizers and farmyard manure with various levels and their interaction in relation to days of flowering, maturity and tuber dry matter yield are shown below (Table 1 and Table 2). $\mathrm{N}$ and P significantly influence number of days to flowering of the crop. However, farm yard manure did not affect this parameter of the plant. Decreasing in days to flowering continued up to the highest level of both nutrient at $111 \mathrm{~kg} \mathrm{~N} \mathrm{ha}^{-1}$ and $92 \mathrm{~kg}$ $\mathrm{P}_{2} \mathrm{O}_{5} \mathrm{ha}^{-1}$ or when fertilizer application supply was raised from $55.5 \mathrm{~kg} \mathrm{~N} \mathrm{ha}^{-1}$ to $111 \mathrm{~kg} \mathrm{~N} \mathrm{ha}^{-1}$ and $46 \mathrm{~kg} \mathrm{P}_{2} \mathrm{O}_{5} \mathrm{ha}^{-1}$ to $92 \mathrm{~kg} \mathrm{P}_{2} \mathrm{O}_{5} \mathrm{ha}^{-1}$. The highest value for days to flowering was recorded at the control treatment which is lowest rate of nutrient,

Table 1. Main effects of $\mathrm{N}$ and $\mathrm{P}_{2} \mathrm{O}_{5}$ fertilizers and farmyard manure on days to flowering, days to maturity and tuber dry matter.

\begin{tabular}{cccc}
\hline Variable & Days of flowering & Days of maturity & Tuber dry matter (t/ha) \\
\hline Organic manure (FYM) & & & \\
Control & 38.07 & 109.4 & $2.028 \mathrm{~b}$ \\
5 ton FYM ha ${ }^{-1}$ & 37.88 & 109.07 & $2.94 \mathrm{a}$ \\
10 ton FYM ha ${ }^{-1}$ & 38.11 & 109.04 & $2.86 \mathrm{a}$ \\
$\mathrm{CV}(\%)$ & 4.67 & 1.46 & 28.81 \\
$\mathrm{SEM}( \pm)$ & 1.77 & 1.59 & 0.75 \\
Inorganic fertilizer N, $\mathrm{P}_{2} \mathrm{O}_{5}$ & & & $2.029 \mathrm{~b}$ \\
$\mathrm{Control}$ & $38.55 \mathrm{a}$ & $109.96 \mathrm{a}$ & $2.79 \mathrm{a}$ \\
$55.5 \mathrm{Kg} \mathrm{N} \mathrm{ha}^{-1}$ & $38.18 \mathrm{ab}$ & $109.48 \mathrm{a}$ & $3.01 \mathrm{a}$ \\
$111 \mathrm{Kg} \mathrm{N}^{-1} \mathrm{RDF}$ & $37.33 \mathrm{~b}$ & $108.07 \mathrm{~b}$ & 28.81 \\
$\mathrm{CV}(\%)$ & 4.67 & 1.45 & 0.75 \\
$\mathrm{SEM}( \pm)_{\mathrm{Control}}$ & 1.77 & 1.59 & $2.318 \mathrm{~b}$ \\
$46 \mathrm{~kg} \mathrm{P}_{2} \mathrm{O}_{5} \mathrm{ha}^{-1}$ & $39.48 \mathrm{a}$ & $109.81 \mathrm{a}$ & $2.501 \mathrm{~b}$ \\
$92 \mathrm{~kg} \mathrm{P}_{2} \mathrm{O}_{5} \mathrm{ha}^{-1} \mathrm{RDF}$ & $37.62 \mathrm{~b}$ & $109.15 \mathrm{ab}$ & $3.01 \mathrm{a}$ \\
$\mathrm{CV}(\%)^{\mathrm{SEM}( \pm)}$ & $36.96 \mathrm{~b}$ & $108.56 \mathrm{~b}$ & 28.81 \\
\hline
\end{tabular}

Means with similar letter within a column are not significantly different at 0.05 probability level, DMRT test, $\mathrm{RDF}=$ Recommended dose of fertilizer, $\mathrm{FYM}=$ Farm yard manure $\mathrm{N}=$ Nitrogen, $\mathrm{P}_{2} \mathrm{O}_{5} \mathrm{~kg} / \mathrm{ha}=$ phosphorus. 
Table 2. Interaction effect of integrated nutrient management practices on days to flowering, days to maturity and tuber dry matter.

\begin{tabular}{|c|c|c|c|}
\hline Treatment & $\begin{array}{l}\text { Days to } \\
\text { Flowering }\end{array}$ & $\begin{array}{l}\text { Days to } \\
\text { Maturity }\end{array}$ & $\begin{array}{c}\text { Tuber Dry } \\
\text { Matter \% }\end{array}$ \\
\hline Control & $42.66 \mathrm{a}$ & $112.67 \mathrm{a}$ & $1.16 \mathrm{e}$ \\
\hline $46 \mathrm{~kg} \mathrm{P}_{2} \mathrm{O}_{5} \mathrm{ha}^{-1}$ & $37.6 \mathrm{~b}-\mathrm{d}$ & $111 \mathrm{ab}$ & $1.105 \mathrm{e}$ \\
\hline $92 \mathrm{~kg} \mathrm{P}_{2} \mathrm{O}_{5} \mathrm{ha}^{-1}$ & $37 b-d$ & $108.67 \mathrm{bc}$ & $1.84 \mathrm{ed}$ \\
\hline $55.5 \mathrm{~kg} \mathrm{~N} \mathrm{ha}^{-1}$ & $40 \mathrm{ab}$ & $110.33 \mathrm{a}-\mathrm{c}$ & $1.82 \mathrm{ed}$ \\
\hline $55.5 \mathrm{~kg} \mathrm{~N} \mathrm{ha}^{-1}+46 \mathrm{~kg} \mathrm{P}_{2} \mathrm{O}_{5} \mathrm{ha}^{-1}$ & $38.66 \mathrm{bc}$ & $110 a-c$ & $2.14 c-e$ \\
\hline $55.5 \mathrm{~kg} \mathrm{~N} \mathrm{ha}^{-1}+92 \mathrm{~kg} \mathrm{P}_{2} \mathrm{O}_{5} \mathrm{ha}^{-1}$ & $37.33 b-d$ & $110 \mathrm{a}-\mathrm{c}$ & $2.458 \mathrm{~b}-\mathrm{d}$ \\
\hline $111 \mathrm{~kg} \mathrm{~N} \mathrm{ha}^{-1}$ & $39 \mathrm{bc}$ & $108.67 \mathrm{bc}$ & $1.76 \mathrm{de}$ \\
\hline $111 \mathrm{~kg} \mathrm{~N} \mathrm{ha}^{-1}+46 \mathrm{~kg} \mathrm{P}_{2} \mathrm{O}_{5} \mathrm{ha}^{-1}$ & $35.66 \mathrm{~cd}$ & $108 \mathrm{~b}-\mathrm{d}$ & $2.52 \mathrm{~b}-\mathrm{e}$ \\
\hline $111 \mathrm{~kg} \mathrm{~N} \mathrm{ha}^{-1}+92 \mathrm{~kg} \mathrm{P}_{2} \mathrm{O}_{5} \mathrm{ha}^{-1}$ & $34.66 \mathrm{~d}$ & $105.33 \mathrm{~d}$ & $3.438 \mathrm{abc}$ \\
\hline $5 \mathrm{t} \mathrm{FYM} \mathrm{ha}^{-1}$ & $38.66 \mathrm{bc}$ & $110 \mathrm{a}-\mathrm{c}$ & $2.487 \mathrm{~b}-\mathrm{e}$ \\
\hline $5 \mathrm{t} \mathrm{FYM} \mathrm{ha}^{-1}+46 \mathrm{~kg} \mathrm{P}_{2} \mathrm{O}_{5} \mathrm{ha}^{-1}$ & $37.66 b-d$ & $109.33 b c$ & $2.48 \mathrm{~b}-\mathrm{e}$ \\
\hline 5 t FYM ha ${ }^{-1}+92 \mathrm{~kg} \mathrm{P}_{2} \mathrm{O}_{5} \mathrm{ha}^{-1}$ & $39 \mathrm{bc}$ & $109 \mathrm{bc}$ & $2.8 \mathrm{a}-\mathrm{d}$ \\
\hline $5 \mathrm{t} \mathrm{FYM} \mathrm{ha}^{-1}+46 \mathrm{~kg} \mathrm{~N} \mathrm{ha}^{-1}$ & $39 \mathrm{bc}$ & $108.67 \mathrm{bc}$ & $2.777 \mathrm{a}-\mathrm{d}$ \\
\hline $5 \mathrm{t} \mathrm{FYM} \mathrm{ha}^{-1}+55.5 \mathrm{~kg} \mathrm{~N} \mathrm{ha}^{-1}+46 \mathrm{~kg} \mathrm{P}_{2} \mathrm{O}_{5} \mathrm{ha}^{-1}$ & $37.66 \mathrm{~b}-\mathrm{d}$ & $109.67 \mathrm{a}-\mathrm{c}$ & $3.82 \mathrm{ab}$ \\
\hline $5 \mathrm{t} \mathrm{FYM} \mathrm{ha}^{-1}+55.5 \mathrm{~kg} \mathrm{~N} \mathrm{ha}^{-1}+92 \mathrm{~kg} \mathrm{P}_{2} \mathrm{O}_{5} \mathrm{ha}^{-1}$ & $36.33 \mathrm{~cd}$ & $109.33 \mathrm{bc}$ & $3.11 \mathrm{a}-\mathrm{d}$ \\
\hline 5 ton FYM ha ${ }^{-1}+111 \mathrm{~kg} \mathrm{~N} \mathrm{ha}^{-1}$ & $39 \mathrm{bc}$ & $109.33 \mathrm{bc}$ & $2.778 \mathrm{a}-\mathrm{d}$ \\
\hline $5 \mathrm{t} \mathrm{FYM} \mathrm{ha}^{-1}+111 \mathrm{~kg} \mathrm{Nha}^{-1}+46 \mathrm{~kg} \mathrm{P}_{2} \mathrm{O}_{5} \mathrm{ha}^{-1}$ & $38 b-d$ & $108 \mathrm{~cd}$ & $2.789 a-d$ \\
\hline $5 \mathrm{t} \mathrm{FYM} \mathrm{ha}^{-1}+111 \mathrm{~kg} \mathrm{Nha}^{-1}+92 \mathrm{~kg} \mathrm{P}_{2} \mathrm{O}_{5} \mathrm{ha}^{-1}$ & $35.66 \mathrm{~cd}$ & $108.33 b c$ & $3.436 \mathrm{abc}$ \\
\hline $10 \mathrm{t} \mathrm{FYM} \mathrm{ha}^{-1}$ & $39 \mathrm{bc}$ & $109.67 \mathrm{a}-\mathrm{c}$ & $2.16 c-e$ \\
\hline 10 t FYM ha ${ }^{-1}+46 \mathrm{~kg} \mathrm{P}_{2} \mathrm{O}_{5} \mathrm{ha}^{-1}$ & $38 b-d$ & $109.67 \mathrm{a}-\mathrm{c}$ & $1.77 \mathrm{ed}$ \\
\hline 10 t FYM ha ${ }^{-1}+92 \mathrm{~kg} \mathrm{P}_{2} \mathrm{O}_{5} \mathrm{ha}^{-1}$ & $37.33 b-d$ & $109.67 \mathrm{a}-\mathrm{c}$ & $2.45 \mathrm{~b}-\mathrm{e}$ \\
\hline $10 \mathrm{t} \mathrm{FYM} \mathrm{ha}^{-1}+55.5 \mathrm{~kg} \mathrm{~N} \mathrm{ha}^{-1}$ & $39 \mathrm{bc}$ & $110.33 \mathrm{a}-\mathrm{c}$ & $3.12 \mathrm{a}-\mathrm{d}$ \\
\hline $10 \mathrm{t} \mathrm{FYM} \mathrm{ha}^{-1}+55.5 \mathrm{~kg} \mathrm{~N} \mathrm{ha}^{-1}+46 \mathrm{~kg} \mathrm{P}_{2} \mathrm{O}_{5} \mathrm{ha}^{-1}$ & $37 b-d$ & $109 b c$ & $2.44 \mathrm{~b}-\mathrm{e}$ \\
\hline 10 t FYM ha ${ }^{-1}+55.5 \mathrm{~kg} \mathrm{~N} \mathrm{ha}^{-1}+92 \mathrm{~kg} \mathrm{P}_{2} \mathrm{O}_{5} \mathrm{ha}^{-1}$ & $38.66 \mathrm{bc}$ & $108 \mathrm{~b}-\mathrm{d}$ & $3.439 \mathrm{abc}$ \\
\hline $10 \mathrm{t} \mathrm{FYM} \mathrm{ha}^{-1}+111 \mathrm{~kg} \mathrm{~N} \mathrm{ha}^{-1}$ & $39 \mathrm{bc}$ & $108.67 \mathrm{bc}$ & $2.79 a-d$ \\
\hline 10 t FYM ha ${ }^{-1}+111 \mathrm{~kg} \mathrm{~N} \mathrm{ha}^{-1}+46 \mathrm{~kg} \mathrm{P}_{2} \mathrm{O}_{5} \mathrm{ha}^{-1}$ & $38.33 \mathrm{bc}$ & $107.67 \mathrm{~cd}$ & $3.438 \mathrm{abc}$ \\
\hline 10 t FYM ha ${ }^{-1}+111 \mathrm{~kg} \mathrm{~N} \mathrm{ha}^{-1}+92 \mathrm{~kg} \mathrm{P}_{2} \mathrm{O}_{5} \mathrm{ha}^{-1}$ & $36.66 \mathrm{~b}-\mathrm{d}$ & $108.67 \mathrm{bc}$ & $4.15 \mathrm{a}$ \\
\hline CV (\%) & 4.47 & 1.42 & 29.89 \\
\hline $\operatorname{SEM}( \pm)$ & 1.69 & 1.55 & 0.78 \\
\hline
\end{tabular}

Means with similar letter within a column are not significantly different at 0.05 probability level, DMRT test, $\mathrm{RDF}=$ Recommended dose of fertilizer, $\mathrm{FYM}=$ Farm yard manure, $\mathrm{N}=$ Nitrogen, $\mathrm{P}_{2} \mathrm{O}_{5}=$ phosphorus.

and higher number of days to flowering obtained for plants in the highest rate of treatment of organic manure. The combination of different rates of inorganic fertilizers (111 $\mathrm{kg} \mathrm{N} \mathrm{ha}^{-1}$ and $92 \mathrm{~kg} \mathrm{P}_{2} \mathrm{O}_{5} \mathrm{ha}^{-1}$ ) with various levels of FYM was significantly influence days to flowering. Thus, the lowest day to flowering was 
attained and hastened significantly due to application of the highest rate $(92 \mathrm{~kg}$ $\mathrm{P}_{2} \mathrm{O}_{5} \mathrm{ha}^{-1}$ ), the lowest than all treatments. This result agreed with the findings of [15]. In addition to this, plants deficient in phosphorus delay in maturity and show stunting of growth [16]. $111 \mathrm{~kg} \mathrm{~N} \mathrm{ha}^{-1}$ and $92 \mathrm{~kg} \mathrm{P}_{2} \mathrm{O}_{5}$ ha $^{-1}$ fertilizer application was significantly influence days to maturity of the crop. However, days to maturity were not significantly affected by application of different rates of farmyard manure (Table 1).

The interaction of different rates of inorganic fertilizers with various levels of FYM has a significant effect on days to maturity. The reduced in day to maturity continued up to the highest level of the nutrient $\left(111 \mathrm{~kg} \mathrm{~N} \mathrm{ha}^{-1}+92 \mathrm{~kg} \mathrm{P}_{2} \mathrm{O}_{5} \mathrm{ha}^{-1}\right.$ +10 ton $\mathrm{FYM} \mathrm{ha}^{-1}$ ) (Table 2). It was the lowest day to maturity 105.33 was recorded due to application of full recommended dose of inorganic fertilizers (111 $\mathrm{kg} \mathrm{N} \mathrm{ha}^{-1}+92 \mathrm{~kg} \mathrm{P}_{2} \mathrm{O}_{5} \mathrm{ha}^{-1}$ ) whereas in the control treatment in longest maturity period about 112.67 days was recorded. The results of the experiment agree with the findings of [17] who reported that integration of organic manure with inorganic fertilizers fasten maturity period of the crop.

\subsection{Tuber Dry Matter}

The result revealed that main effects of organic and inorganic fertilizer showed significant difference for tuber dry matter yield (Table 1). The treatment that received recommended dose of $111 \mathrm{~kg} \mathrm{~N} \mathrm{ha}^{-1}$ and $92 \mathrm{~kg} \mathrm{P}_{2} \mathrm{O}_{5} \mathrm{ha}^{-1}$ fertilizer significantly increased tuber dry matter yield. Similarly, the effect of 5 ton FYM $\mathrm{ha}^{-1}$ application on tuber dry matter yield was statistically significant compared to the control treatment.

The combination of different rates of inorganic fertilizer ( $\mathrm{N}$ and $\mathrm{P}$ ) with various level of farm yard manure (FYM) caused significant differences in tuber dry matter yield.

Treatment that received recommended dose of organic and inorganic fertilizer $\left(10 \mathrm{t} \mathrm{FYM} \mathrm{ha}{ }^{-1}+111 \mathrm{~kg} \mathrm{~N} \mathrm{ha}^{-1}+92 \mathrm{~kg} \mathrm{P}_{2} \mathrm{O}_{5} \mathrm{ha}^{-1}\right)$ gave significantly higher tuber dry matter yield (4.15 $\mathrm{t} / \mathrm{ha}$ ) (Table 2). [18] also reported that combined use of organic manure increased the dry matter production than control plots. Treatments that $10 \mathrm{t} \mathrm{FYM} \mathrm{ha}^{-1}+111 \mathrm{~N} \mathrm{~kg} \mathrm{ha}^{-1}+46 \mathrm{~kg} \mathrm{P}_{2} \mathrm{O}_{5} \mathrm{ha}^{-1}$ and $10 \mathrm{t} \mathrm{FYM} \mathrm{ha}^{-1}+$ $55.5 \mathrm{~N} \mathrm{~kg} \mathrm{ha}^{-1}+92 \mathrm{~kg} \mathrm{P}_{2} \mathrm{O}_{5} \mathrm{ha}^{-1}$ and $111 \mathrm{~N} \mathrm{~kg} \mathrm{ha}^{-1}+92 \mathrm{~kg} \mathrm{P}_{2} \mathrm{O}_{5} \mathrm{ha}^{-1}$ also resulted in higher tuber dry matter production. The result revealed that interaction of organic manures with various rate of inorganic fertilizer could give better dry matter production than in organic and inorganic alone. The present finding is in conformity with the finding of [19] who reported that integrated nutrient supply increased dry matter yield of potato.

\subsection{Growth Parameters}

\subsubsection{Number of Main Stem}

The results of analysis of variance for growth components of potato under interaction of organic and inorganic fertilizer are presented and discuss here below. The result showed that neither the main effect of inorganic fertilizer nor that of 
organic (farmyard manure) application had not affected significantly on main stem number per hill (Table 3).

In the some way, the interaction effects of different rates of recommended dose of inorganic fertilizers ( $\mathrm{N}$ and $\mathrm{P}$ ) with various level of FYM were non-significant $(p<0.05)$ in $($ Table 4$)$. The maximum number of main stem recorded was $(8.25)$ in the plots received a dose of organic and inorganic fertilizer $\left(10 \mathrm{tFM} \mathrm{ha}^{-1}+\right.$ $111 \mathrm{~kg} \mathrm{~N} \mathrm{ha}^{-1}+46 \mathrm{~kg} \mathrm{P}_{2} \mathrm{O}_{5} \mathrm{ha}^{-1}$ ), which followed by a half dose of organic and inorganic fertilizer ( $5 \mathrm{t} \mathrm{FYM} \mathrm{ha}{ }^{-1}+55.5 \mathrm{~kg} \mathrm{~N} \mathrm{ha}^{-1}+46 \mathrm{~kg} \mathrm{P}_{2} \mathrm{O}_{5} \mathrm{ha}^{-1}$ (8.24)). [20] also stated that the number of stems/hill did not differ significantly due to the application of different levels of $\mathrm{N}, \mathrm{P}_{2} \mathrm{O}_{5}$ and FYM as well as their combination. In this study application of both organic and inorganic fertilizers had no any effect on the number of main stem of potato.

\subsubsection{Plant Height}

The application of organic and inorganic fertilizers had significant for the main effects of plant height (Table 3). Plant height significantly increased from 89.63 to $91.39 \mathrm{~cm}$ when FYM supply was raised from 5 to $10 \mathrm{tha}^{-1}$. In the same way,

Table 3. Main effect of $\mathrm{N}$ and $\mathrm{P}_{2} \mathrm{O}_{5}$ inorganic fertilizers and FYM practices on growth component of potato.

\begin{tabular}{|c|c|c|c|c|}
\hline Treatments & $\begin{array}{l}\text { Number of } \\
\text { main stem }\end{array}$ & $\begin{array}{l}\text { Plant height } \\
(\mathrm{cm})\end{array}$ & $\begin{array}{l}\text { Total leaf } \\
\text { area }\left(\mathrm{cm}^{2}\right)\end{array}$ & $\begin{array}{c}\text { Above ground } \\
\text { biomass }\left(\mathrm{kg} \mathrm{ha}^{-1}\right)\end{array}$ \\
\hline \multicolumn{5}{|l|}{ Organic manure (FYM) } \\
\hline Control & 7.69 & $85 b$ & $16.4 \mathrm{c}$ & $0.19 \mathrm{a}$ \\
\hline $5 \mathrm{t} \mathrm{FYM} \mathrm{ha}^{-1}$ & 7.93 & $89.63 a$ & $17.034 b$ & $0.21 \mathrm{ab}$ \\
\hline $10 \mathrm{t} \mathrm{FYM} \mathrm{ha}^{-1}$ & 7.89 & $91.39 \mathrm{a}$ & $17.9 \mathrm{a}$ & $0.22 b$ \\
\hline CV (\%) & 11.39 & 6.98 & 6.35 & 23.74 \\
\hline $\operatorname{SEM}( \pm)$ & 0.89 & 6.187 & 1.09 & 50.02 \\
\hline \multicolumn{5}{|l|}{ Inorganic fertilizer $\mathrm{N}, \mathrm{P}_{2} \mathrm{O}_{5}$} \\
\hline Control & 7.69 & $85.46 \mathrm{~b}$ & $16.239 \mathrm{c}$ & $0.19 b$ \\
\hline $55.5 \mathrm{~kg} \mathrm{~N} \mathrm{ha}^{-1}$ & 7.86 & $88.11 \mathrm{~b}$ & $17.128 \mathrm{~b}$ & $0.2 \mathrm{~b}$ \\
\hline $111 \mathrm{~kg} \mathrm{~N} \mathrm{ha}^{-1} \mathrm{RDF}$ & 7.96 & $92.43 \mathrm{a}$ & $17.969 a$ & $0.24 \mathrm{a}$ \\
\hline CV (\%) & 11.39 & 6.98 & 6.35 & 23.74 \\
\hline $\operatorname{SEM}( \pm)$ & 0.89 & 6.19 & 1.09 & 50.02 \\
\hline control & 7.71 & $86.64 b$ & $16.63 b$ & 0.2 \\
\hline $46 \mathrm{~kg} \mathrm{P}_{2} \mathrm{O}_{5} \mathrm{ha}^{-1}$ & 7.88 & $89.27 \mathrm{ab}$ & $17.28 \mathrm{a}$ & 0.2 \\
\hline $92 \mathrm{~kg} \mathrm{P}_{2} \mathrm{O}_{5} \mathrm{ha}^{-1} \mathrm{RDF}$ & 7.91 & $90.11 \mathrm{a}$ & $17.42 \mathrm{a}$ & 0.22 \\
\hline CV (\%) & 11.39 & 6.98 & 6.35 & 23.74 \\
\hline SEM $( \pm)$ & 0.89 & 6.18 & 1.08 & 50.02 \\
\hline
\end{tabular}

Means with similar letter within a column are not significantly different at 0.05 probability level, DMRT test, $\mathrm{RDF}=$ Recommended dose of fertilizer, $\mathrm{FYM}=$ Farm yard manure, $\mathrm{N}=$ Nitrogen, $\mathrm{P}_{2} \mathrm{O}_{5}=$ phosphorus penta oxide. 
Table 4. Interaction effect of integrated nutrient management practices on growth parameters of potato.

\begin{tabular}{|c|c|c|c|c|}
\hline Treatments & Nms & $\begin{array}{l}\mathrm{Ph} \\
\mathrm{Cm}\end{array}$ & $\begin{array}{l}\text { TLA } \\
\mathrm{cm}^{2}\end{array}$ & $\begin{array}{c}\mathrm{AGB} \\
\left(\mathrm{kg} \mathrm{ha}^{-1}\right)\end{array}$ \\
\hline Control & 7.48 & $65.7 \mathrm{~d}$ & $13.89 \mathrm{f}$ & $0.11 \mathrm{e}$ \\
\hline $46 \mathrm{~kg} \mathrm{P}_{2} \mathrm{O}_{5} \mathrm{ha}^{-1}$ & 7.66 & $82.46 \mathrm{c}$ & $15.65 \mathrm{e}$ & $0.19-\mathrm{e}$ \\
\hline $92 \mathrm{~kg} \mathrm{P}_{2} \mathrm{O}_{5} \mathrm{ha}^{-1}$ & 7.82 & $88.2 \mathrm{a}-\mathrm{c}$ & $16.76 \mathrm{~b}-\mathrm{e}$ & $0.2-d$ \\
\hline $55.5 \mathrm{~kg} \mathrm{~N} \mathrm{ha}^{-1}$ & 7.5 & $84 \mathrm{bc}$ & $15.76 \mathrm{e}$ & $0.18-\mathrm{e}$ \\
\hline $55.5 \mathrm{~kg} \mathrm{~N} \mathrm{ha}^{-1}+46 \mathrm{~kg} \mathrm{P}_{2} \mathrm{O}_{5} \mathrm{ha}^{-1}$ & 7.8 & $86 a-c$ & $15.99 \mathrm{de}$ & $0.21 \mathrm{a}-\mathrm{d}$ \\
\hline $55.5 \mathrm{~kg} \mathrm{~N} \mathrm{ha}^{-1}+92 \mathrm{~kg} \mathrm{P}_{2} \mathrm{O}_{5} \mathrm{ha}^{-1}$ & 7.73 & $86.2 \mathrm{a}-\mathrm{c}$ & $16.63 c-e$ & $0.18 \mathrm{~b}-\mathrm{e}$ \\
\hline $111 \mathrm{~kg} \mathrm{~N} \mathrm{ha}^{-1}$ & 7.7 & $88.06 \mathrm{a}-\mathrm{c}$ & $17.09 \mathrm{~b}-\mathrm{e}$ & $0.21 \mathrm{a}-\mathrm{d}$ \\
\hline $111 \mathrm{~kg} \mathrm{~N} \mathrm{ha}^{-1}+46 \mathrm{~kg} \mathrm{P}_{2} \mathrm{O}_{5} \mathrm{ha}^{-1}$ & 7.68 & $88.66 \mathrm{a}-\mathrm{c}$ & $16.95 b-e$ & $0.22 \mathrm{a}-\mathrm{d}$ \\
\hline $111 \mathrm{~kg} \mathrm{~N} \mathrm{ha}^{-1}+92 \mathrm{~kg} \mathrm{P}_{2} \mathrm{O}_{5} \mathrm{ha}^{-1}$ & 7.83 & $95.6 \mathrm{a}$ & $18.86 \mathrm{ab}$ & $0.24 \mathrm{a}-\mathrm{c}$ \\
\hline $5 \mathrm{t} \mathrm{FYM} \mathrm{ha}^{-1}$ & 7.73 & $86.4 \mathrm{a}-\mathrm{c}$ & $16.03 \mathrm{de}$ & $0.18 \mathrm{~b}-\mathrm{e}$ \\
\hline $5 \mathrm{t} \mathrm{FYM} \mathrm{ha}^{-1}+46 \mathrm{~kg} \mathrm{P}_{2} \mathrm{O}_{5} \mathrm{ha}^{-1}$ & 7.7 & $85.5 \mathrm{a}-\mathrm{c}$ & $16.55 \mathrm{c}-\mathrm{e}$ & $0.13 \mathrm{de}$ \\
\hline 5 t FYM ha ${ }^{-1}+92 \mathrm{~kg} \mathrm{P}_{2} \mathrm{O}_{5} \mathrm{ha}^{-1}$ & 7.88 & $88 \mathrm{a}-\mathrm{c}$ & $16.35 c-e$ & $0.23 \mathrm{a}-\mathrm{d}$ \\
\hline $5 \mathrm{t} \mathrm{FYM} \mathrm{ha}^{-1}+46 \mathrm{~kg} \mathrm{~N} \mathrm{ha}^{-1}$ & 7.84 & $87.4 \mathrm{a}-\mathrm{c}$ & $16.47 \mathrm{c}-\mathrm{e}$ & $0.24 \mathrm{a}-\mathrm{c}$ \\
\hline $5 \mathrm{t} \mathrm{FYM} \mathrm{ha}^{-1}+55.5 \mathrm{~kg} \mathrm{~N} \mathrm{ha}^{-1}+46 \mathrm{~kg} \mathrm{P}_{2} \mathrm{O}_{5} \mathrm{ha}^{-1}$ & 8.24 & $92.5 \mathrm{a}-\mathrm{c}$ & $18.02 \mathrm{a}-\mathrm{d}$ & $0.23-\mathrm{d}$ \\
\hline $5 \mathrm{t} \mathrm{FYM} \mathrm{ha}^{-1}+55.5 \mathrm{~kg} \mathrm{~N} \mathrm{ha}^{-1}+92 \mathrm{~kg} \mathrm{P}_{2} \mathrm{O}_{5} \mathrm{ha}^{-1}$ & 7.83 & $86.33 a-c$ & $17.07 \mathrm{~b}-\mathrm{e}$ & $0.21 \mathrm{a}-\mathrm{d}$ \\
\hline 5 ton FYM ha ${ }^{-1}+111 \mathrm{~kg} \mathrm{~N} \mathrm{ha}^{-1}$ & 7.91 & $93.5 \mathrm{ab}$ & $17.58 \mathrm{a}-\mathrm{e}$ & $0.21 \mathrm{a}-\mathrm{d}$ \\
\hline 5 t FYM ha ${ }^{-1}+111 \mathrm{~kg} \mathrm{~N} \mathrm{ha}^{-1}+46 \mathrm{~kg} \mathrm{P}_{2} \mathrm{O}_{5} \mathrm{ha}^{-1}$ & 8.2 & $93.73 \mathrm{ab}$ & $17.5 \mathrm{a}-\mathrm{e}$ & $0.2 \mathrm{a}-\mathrm{d}$ \\
\hline $5 \mathrm{t} \mathrm{FYM} \mathrm{ha}^{-1}+111 \mathrm{~kg} \mathrm{Nha}^{-1}+92 \mathrm{~kg} \mathrm{P}_{2} \mathrm{O}_{5} \mathrm{ha}^{-1}$ & 8 & $93.26 \mathrm{a}-\mathrm{c}$ & $17.71 \mathrm{a}-\mathrm{e}$ & $0.21 \mathrm{a}-\mathrm{d}$ \\
\hline $10 \mathrm{t} \mathrm{FYM} \mathrm{ha}^{-1}$ & 7.33 & $92.15 \mathrm{a}-\mathrm{c}$ & $17.2 \mathrm{~b}-\mathrm{e}$ & $0.23 \mathrm{a}-\mathrm{d}$ \\
\hline $10 \mathrm{t} \mathrm{FYM} \mathrm{ha}^{-1}+46 \mathrm{~kg} \mathrm{P}_{2} \mathrm{O}_{5} \mathrm{ha}^{-1}$ & 7.77 & $90 a-c$ & $17.15 b-e$ & $0.17 \mathrm{c}-\mathrm{e}$ \\
\hline 10 t FYM ha ${ }^{-1}+92 \mathrm{~kg} \mathrm{P}_{2} \mathrm{O}_{5} \mathrm{ha}^{-1}$ & 7.83 & $90.7 \mathrm{a}-\mathrm{c}$ & $16.54 \mathrm{c}-\mathrm{e}$ & $0.2 \mathrm{a}-\mathrm{d}$ \\
\hline $10 \mathrm{t} \mathrm{FYM} \mathrm{ha}{ }^{-1}+55.5 \mathrm{~kg} \mathrm{~N} \mathrm{ha}^{-1}$ & 7.9 & $88.5 \mathrm{a}-\mathrm{c}$ & 17.43a-e & $0.19 \mathrm{a}-\mathrm{e}$ \\
\hline $10 \mathrm{t} \mathrm{FYM} \mathrm{ha}^{-1}+55.5 \mathrm{~kg} \mathrm{~N} \mathrm{ha}^{-1}+46 \mathrm{~kg} \mathrm{P}_{2} \mathrm{O}_{5} \mathrm{ha}^{-1}$ & 7.8 & $94.9 \mathrm{a}$ & $19.26 \mathrm{a}$ & $0.17 \mathrm{c}-\mathrm{e}$ \\
\hline $10 \mathrm{t} \mathrm{FYM} \mathrm{ha}^{-1}+55.5 \mathrm{~kg} \mathrm{~N} \mathrm{ha}^{-1}+92 \mathrm{~kg} \mathrm{P}_{2} \mathrm{O}_{5} \mathrm{ha}^{-1}$ & 8.1 & $87.06 a-c$ & $17.49 \mathrm{a}-\mathrm{e}$ & $0.22 \mathrm{a}-\mathrm{d}$ \\
\hline $10 \mathrm{t} \mathrm{FYM} \mathrm{ha}^{-1}+111 \mathrm{~kg} \mathrm{~N} \mathrm{ha}^{-1}$ & 7.93 & $93.86 \mathrm{ab}$ & $18.22 \mathrm{a}-\mathrm{c}$ & $0.27 \mathrm{ab}$ \\
\hline 10 t FYM ha ${ }^{-1}+111 \mathrm{~kg} \mathrm{~N} \mathrm{ha}^{-1}+46 \mathrm{~kg} \mathrm{P}_{2} \mathrm{O}_{5} \mathrm{ha}^{-1}$ & 8.11 & $89.6 \mathrm{a}-\mathrm{c}$ & $18.44 \mathrm{a}-\mathrm{c}$ & $0.27 \mathrm{ab}$ \\
\hline 10 t FYM ha ${ }^{-1}+111 \mathrm{~kg} \mathrm{~N} \mathrm{ha}^{-1}+92 \mathrm{~kg} \mathrm{P}_{2} \mathrm{O}_{5} \mathrm{ha}^{-1}$ & 8.25 & $95.6 \mathrm{a}$ & $19.35 \mathrm{a}$ & $0.28 \mathrm{a}$ \\
\hline $\mathrm{CV}(\%)$ & 13.26 & 6.09 & 6.11 & 22.81 \\
\hline $\operatorname{SEM}( \pm)$ & 1.02 & 2.32 & 1.02 & 6.98 \\
\hline
\end{tabular}

Means with similar letter within a column are not significantly different at 0.05 probability level, DMRT test, $\mathrm{RDF}=$ Recommended dose of fertilizer, $\mathrm{FYM}=$ Farm yard manure, $\mathrm{N}=$ nitrogen, $\mathrm{P}_{2} \mathrm{O}_{5}=$ phosphorus penta oxide, $\mathrm{Nms}=$ number of main stem, $\mathrm{Ph}=$ Plant height, $\mathrm{TLA}=$ Total leaf area, $\mathrm{AGB}=$ Above ground biomass.

plant height increased from 88.11 to $92.43 \mathrm{~cm}$ and from 89.27 to $90.11 \mathrm{~cm}$ when inorganic fertilizer supply was raised from $55.5 \mathrm{~kg} \mathrm{~N} \mathrm{ha}^{-1}-111 \mathrm{~kg} \mathrm{~N} \mathrm{ha}^{-1}$ and 46 
$\mathrm{kg} \mathrm{ha}^{-1}-92 \mathrm{~kg} \mathrm{P}_{2} \mathrm{O}_{5} \mathrm{ha}^{-1}$ respectively. The plant height was grown in the treatment of $111 \mathrm{~kg} \mathrm{~N} \mathrm{ha}^{-1}$, which was higher than that in the control treatment and other main effect. The increase in plant height might be due to cell division and enlargement, which is stimulated by presence of nitrogen. These results were confirmed by [21] who advocated that increasing $\mathrm{N}$ level significantly increased plant height.

Plant height was significantly influenced by the application of different rates of inorganic fertilizers $\left(111 \mathrm{~kg} \mathrm{~N} \mathrm{ha}^{-1}\right.$ and $92 \mathrm{~kg} \mathrm{P}_{2} \mathrm{O}_{5} \mathrm{ha}^{-1}$ ) with different rate of farm yard manure (Table 4). This might be due to the positive effects of organic and inorganic fertilizer through adequate supply of all nutrients. The inorganic fertilizer in combined with application of FYM might have enhanced the decomposition of organic matter thus the increased supply of nutrients for increasing the cell division and elongation. This finding agreed with [22], who stated that the application of organic manure with inorganic fertilizer significantly increased growth and vigor of the plants over application of inorganic fertilizers alone.

The tallest plants height $(95.6 \mathrm{~cm})$ was recorded in the treatment $(10$ ton FYM $\mathrm{ha}^{-1}+111 \mathrm{~kg} \mathrm{~N} \mathrm{ha}^{-1}+92 \mathrm{~kg}_{2} \mathrm{O}_{5} \mathrm{ha}^{-1}$ ), compared with to all other treatments, followed by no application of FYM but had full doze of inorganic fertilizer (95.5 $\mathrm{cm})$. The increase in plant height in the presence of inorganic fertilizer may be due to better availability of nutrients. It was observed that plants that received both organic and inorganic were significantly taller than those in height as compared to plants obtained from the control plot. The current experiment result corroborates the findings of [23] who reported that organic manure and inorganic fertilizer supplied all the essential nutrients at seedling stage resulting in an increase of measured variables like plant height. [18] and [24] also reported the combined effect of organic fertilizer and inorganic fertilizer on the plant height was significant. The increase in plant height might be due to more availability and up take of nutrients. Generally the result revealed that plots that received both organic and inorganic fertilizer produced plants with taller height as compared to plants on controlled plot.

\subsubsection{Above Ground Biomass}

The analysis of variance of main effects revealed that the use of farmyard manure and $\mathrm{N}$ was significantly influence the above ground biomass of the crop, but $\mathrm{P}_{2} \mathrm{O}_{5}$ fertilizers did not affect this parameter of the plant (Table 3). Thus, the highest above ground biomass was attained at the rate of $111 \mathrm{~kg} \mathrm{~N} \mathrm{ha}^{-1}$ and was higher than the above ground biomass obtained for plants in all treatments. The results indicated that inorganic fertilizer $(\mathrm{N})$ increased the above ground biomass from $0.2 \mathrm{~kg} \mathrm{ha}^{-1}$ to $0.24 \mathrm{~kg} \mathrm{ha}^{-1}$ when the rates of nitrogen fertilizer rose from $55.5 \mathrm{~kg} \mathrm{~N} \mathrm{ha}^{-1}$ to $111 \mathrm{~kg} \mathrm{~N} \mathrm{ha}^{-1}$. This result is in conformity with the findings of [25] who reported a significant increment in canopy dry matter yield of potato in response to increased nitrogen application. Similarly [26] also reported that efficient use of inorganic fertilizer increased the above ground biomass. This 
increase in the above ground biomass with increasing rate of inorganic fertilizer could be attributed to the effect of $\mathrm{N}$ on vegetative growth. [27] reported similar results in case of sweet potato.

The analysis of variance showed a highly significant effect of treatments on above ground biomass (Table 4). The results indicated that highest biomass ( 0.28 $\mathrm{kg} \mathrm{ha}^{-1}$ ) was obtained from the combined application of organic and inorganic fertilizer $\left(10 \mathrm{t} \mathrm{FYM} \mathrm{ha}^{-1}+111 \mathrm{~kg} \mathrm{~N} \mathrm{ha}^{-1}+92 \mathrm{~kg} \mathrm{P}_{2} \mathrm{O}_{5} \mathrm{ha}^{-1}\right)$ followed by $(10 \mathrm{t}$ FYM ha $\left.{ }^{-1}+111 \mathrm{~kg} \mathrm{~N} \mathrm{ha}^{-1}+46 \mathrm{~kg} \mathrm{P}_{2} \mathrm{O}_{5} \mathrm{ha}^{-1}\right)(276.32 \mathrm{~g}$ ), which was significantly higher than the above ground biomass obtained from the control plot. However, the lowest above ground biomass was observed in the plot from control $(0.11 \mathrm{~kg}$ $\mathrm{ha}^{-1}$ ). Similar results were reported by [27] for sweet potato.

\subsubsection{Total Leaf Area}

The result indicates farmyard manure was significantly influenced at $(\mathrm{p}<0.05)$ on total leaf area of the crop. Thus, the highest total leaf area was attained at the highest rate of the nutrients from treatment that received (10 ton FYM/ha), and was higher than the total leaf area obtained for plants in the control treatment. The result of the current experiment could probably be attributed to the beneficial effect integrated fertilizer use and the macro as well as micro nutrients supplied through FYM [28] and increased availability of plant nutrients [29]. In the same way, significant difference was observed among different rate of inorganic fertilizers $\mathrm{N}$ (from 55.5 to $111 \mathrm{~kg} \mathrm{ha}^{-1}$ ) and $\mathrm{P}_{2} \mathrm{O}_{5}$ (from 46 to $92 \mathrm{~kg} \mathrm{ha}^{-1}$ ) (Table 4). Nitrogen fertilizer increases the leaf area, which increases the amount of solar radiation intercepted, and consequently, increases dry matter production by different plant parts. It increases potato yields by increasing the number of tubers formed [30], duration of tuber bulking, and nitrogen uptake by the plant [31].

The effect of interaction of different rates of inorganic fertilizer $\left(\mathrm{N}\right.$ and $\mathrm{P}_{2} \mathrm{O}_{5}$ ) with various rates of organic manure (FYM) showed a significant difference. Among the treatments maximum total leaf area was recorded $\left(19.35 \mathrm{~cm}^{2}\right)$ for the treatment that received ( $\left.10 \mathrm{t} \mathrm{FYM} \mathrm{ha}{ }^{-1}+111 \mathrm{~kg} \mathrm{~N} \mathrm{ha}^{-1}+92 \mathrm{~kg} \mathrm{P}_{2} \mathrm{O}_{5} \mathrm{ha}^{-1}\right)$, followed by $10 \mathrm{t}$ FYM ha ${ }^{-1}+55.5 \mathrm{~kg} \mathrm{~N} \mathrm{ha}^{-1}+46 \mathrm{~kg} \mathrm{P}_{2} \mathrm{O}_{5} \mathrm{ha}^{-1}\left(19.26 \mathrm{~cm}^{2}\right)$ (Table 4) was significantly higher than the leaf area obtained in the control. Furthermore, the result of the current experiment was agreed with the finding of [32] who reported the integrated nutrient management practices significantly influenced total leaf area. The higher leaf area as a result of integrated use of organic and inorganic fertilizers might be due to the more availability and up take of nutrients or the release of considerable amounts of nutrients especially $\mathrm{N}$ for plant use. $\mathrm{N}$ is essential for chlorophyll and protoplasm formation [33].

\subsection{Yield and Yield Attributes}

The analysis of result indicated that the main effect of inorganic fertilizer both $\mathrm{N}$ and $\mathrm{P}$ was significantly influenced average tuber mass. The recommended dose of inorganic fertilizer at $111 \mathrm{~kg} \mathrm{~N} \mathrm{ha}^{-1}$ as well as $92 \mathrm{~kg} \mathrm{P}_{2} \mathrm{O}_{5} \mathrm{ha}^{-1}$ showed significantly higher average tuber mass compared to control plot. The increase in av- 
erage tuber mass continued up to the highest level of both inorganic nutrients (111 kg N ha ${ }^{-1}$ and $92 \mathrm{~kg} \mathrm{P}_{2} \mathrm{O}_{5} \mathrm{ha}^{-1}$ ) (Table 5).

On the other hand, the application of farm yard manure had significant effect on average tuber mass; there was increase of average tuber mass with the increasing rates of FYM from nil to $10 \mathrm{tha}^{-1}$. [34] stated that the increase in average tuber mass with the supply of fertilizer nutrients could be due to more growth and higher supply of photo assimilates which helped in producing larger size tubers, hence resulting in higher yields.

The highest average tuber mass (134.03 g/tuber) was obtained in the plot that received $10 \mathrm{t} \mathrm{FYM} \mathrm{ha}{ }^{-1}+111 \mathrm{~kg} \mathrm{~N} \mathrm{ha}^{-1}+92 \mathrm{~kg} \mathrm{P}_{2} \mathrm{O}_{5} \mathrm{ha}^{-1}$ followed by application of $\left(111 \mathrm{~kg} \mathrm{~N} \mathrm{ha}^{-1}+92 \mathrm{~kg} \mathrm{P}_{2} \mathrm{O}_{5} \mathrm{ha}^{-1}\right)$ inorganic fertilizers $\left(105.5 \mathrm{~g} \mathrm{tuber}^{-1}\right)$ which was significantly higher than that control $\left(83.15 \mathrm{~g} \mathrm{tuber}^{-1}\right)$ (Table 6). The result is agreed with the report of [29] who reported that integrated nutrient management practices significantly increased average tuber mass. [32] also stated that a significant increase in tuber yield components with increasing organic manure and inorganic fertilizers might be due to higher nutrient availability, and uptake with higher rates of both fertilizer types and increased availability of plant nutrients, hence resulting in higher yields. Disagree with to the findings of the present study, [35] found no significant influence of organic fertilizer application on average tuber mass.

Table 5. Main effect of $\mathrm{N}$ and $\mathrm{P}_{2} \mathrm{O}_{5}$ inorganic fertilizers and FYM practices on yield and yield attribute of potato.

\begin{tabular}{|c|c|c|c|c|c|c|c|c|}
\hline \multirow{2}{*}{$\begin{array}{c}\text { Treatments } \\
\text { organic manure (FYM) }\end{array}$} & \multicolumn{3}{|c|}{ Tuber numbers } & \multirow{2}{*}{$\begin{array}{l}\text { Average tuber } \\
\text { number }\end{array}$} & \multirow{2}{*}{$\begin{array}{l}\text { Average tuber } \\
\text { mass }(\mathrm{g})\end{array}$} & \multicolumn{3}{|c|}{ Tuber yield (t/ha) } \\
\hline & Mar. & Unmar. & Total & & & Mar. & Unmar. & Total \\
\hline Control & $347.29 \mathrm{~b}$ & $30.96 \mathrm{~b}$ & $378.25 b$ & $12.42 \mathrm{~b}$ & $95.24 \mathrm{~b}$ & $28.37 \mathrm{~b}$ & 1.69 & $30.07 \mathrm{~b}$ \\
\hline $5 \mathrm{t} \mathrm{FYM} \mathrm{ha}^{-1}$ & $385 a$ & $34.33 \mathrm{ab}$ & 419.33a & $13.97 \mathrm{a}$ & $99.14 \mathrm{ab}$ & $34.25 \mathrm{a}$ & 1.85 & $36.11 \mathrm{a}$ \\
\hline $10 \mathrm{t} \mathrm{FYM} \mathrm{ha}^{-1}$ & $388 \mathrm{a}$ & $37.14 \mathrm{a}$ & $425.14 \mathrm{a}$ & $14.23 \mathrm{a}$ & $101.12 \mathrm{a}$ & $34.08 \mathrm{a}$ & 1.92 & $36 a$ \\
\hline CV (\%) & 9.68 & 22.74 & 9 & 9.46 & 9.26 & 9.1 & 30.35 & 8.66 \\
\hline $\operatorname{SEM}( \pm)$ & 36.14 & 7.77 & 36.692 & 1.28 & 9.12 & 2.93 & 0.55 & 2.95 \\
\hline \multicolumn{9}{|l|}{ Inorganic fertilizer } \\
\hline Control & $341.37 \mathrm{c}$ & 32.33 & $373.7 \mathrm{c}$ & $12.27 \mathrm{c}$ & $95.25 b$ & $29.34 b$ & 1.8 & $31.14 \mathrm{~b}$ \\
\hline $55.5 \mathrm{~kg} \mathrm{~N} \mathrm{ha}^{-1}$ & $379.63 b$ & 34.77 & $414.407 \mathrm{~b}$ & $13.82 \mathrm{~b}$ & $96.39 b$ & $33.21 \mathrm{a}$ & 1.93 & $35.15 \mathrm{a}$ \\
\hline $111 \mathrm{~kg} \mathrm{~N} \mathrm{ha}^{-1} \mathrm{RDF}$ & $399.29 a$ & 35.33 & $434.63 a$ & $14.53 \mathrm{a}$ & $103.85 \mathrm{a}$ & $34.16 \mathrm{a}$ & 1.73 & $35.89 \mathrm{a}$ \\
\hline CV (\%) & 9.68 & 22.74 & 9 & 9.46 & 9.26 & 9.1 & 30.35 & 8.66 \\
\hline $\operatorname{SEM}( \pm)$ & 36.14 & 7.77 & 36.692 & 1.28 & 9.12 & 2.93 & 0.55 & 2.95 \\
\hline Control & $357.51 \mathrm{~b}$ & 35.59 & $393.11 \mathrm{~b}$ & $13.07 \mathrm{~b}$ & $94.68 \mathrm{~b}$ & $30.46 \mathrm{~b}$ & 1.7 & $32.17 \mathrm{~b}$ \\
\hline $46 \mathrm{~kg} \mathrm{P}_{2} \mathrm{O}_{5} \mathrm{ha}^{-1}$ & $370.7 \mathrm{~b}$ & 34.148 & $404.85 b$ & $13.4 \mathrm{~b}$ & $97.67 \mathrm{~b}$ & $32.5 \mathrm{a}$ & 1.97 & $34.47 \mathrm{a}$ \\
\hline $92 \mathrm{~kg} \mathrm{P}_{2} \mathrm{O}_{5} \mathrm{ha}^{-1}$ & $392.07 \mathrm{a}$ & 32.70 & $424.77 \mathrm{a}$ & $14.15 \mathrm{a}$ & $103.14 \mathrm{a}$ & $33.75 a$ & 1.79 & $35.54 \mathrm{a}$ \\
\hline CV (\%) & 9.68 & 22.74 & 9 & 9.46 & 9.26 & 9.1 & 30.35 & 8.66 \\
\hline $\operatorname{SEM}( \pm)$ & 36.14 & 7.77 & 36.69 & 1.28 & 9.12 & 2.93 & 0.55 & 2.95 \\
\hline
\end{tabular}

Means with similar letter within a column are not significantly different at 0.05 probability level, DMRT test, Mar $=$ Marketable, Unmar $=$ Unmarketable, $\mathrm{RDF}=$ Recommended dose of fertilizer, $\mathrm{FYM}=$ Farm yard manure, $\mathrm{N}=$ Nitrogen, $\mathrm{P}_{2} \mathrm{O}_{5}=$ phosphorus penta oxide. 
Table 6. Interaction effect of integrated nutrient management on tuber yield and average tuber mass of potato.

\begin{tabular}{|c|c|c|c|c|c|}
\hline \multirow{2}{*}{ No. } & \multirow{2}{*}{ Treatments } & \multicolumn{3}{|c|}{ Tuber Yield } & \multirow{2}{*}{$\begin{array}{c}\text { Average Tuber } \\
\text { Mass (g) }\end{array}$} \\
\hline & & Mark & Unmark & Total & \\
\hline 1 & Control & $21.01 \mathrm{i}$ & 1.81 & $22.83 \mathrm{~h}$ & $83.15 \mathrm{~d}$ \\
\hline 2 & $46 \mathrm{~kg} \mathrm{P}_{2} \mathrm{O}_{5} \mathrm{ha}^{-1}$ & 23.88ih & 1.36 & $25.25 \mathrm{hg}$ & $86.57 \mathrm{~cd}$ \\
\hline 3 & $92 \mathrm{~kg} \mathrm{P}_{2} \mathrm{O}_{5} \mathrm{ha}^{-1}$ & $25.21 \mathrm{~g}-\mathrm{i}$ & 1.68 & $26.89 f-h$ & $93.24 \mathrm{bcd}$ \\
\hline 4 & $55.5 \mathrm{~kg} \mathrm{~N} \mathrm{ha}^{-1}$ & $27.25 f-h$ & 1.5 & $28.75 \mathrm{e}-\mathrm{g}$ & $95.18 \mathrm{bcd}$ \\
\hline 5 & $55.5 \mathrm{~kg} \mathrm{~N} \mathrm{ha}^{-1}+46 \mathrm{~kg} \mathrm{P}_{2} \mathrm{O}_{5} \mathrm{ha}^{-1}$ & $29.64 d-g$ & 1.83 & $31.47 \mathrm{c}-\mathrm{f}$ & $96.42 \mathrm{bcd}$ \\
\hline 6 & $55.5 \mathrm{~kg} \mathrm{~N} \mathrm{ha}^{-1}+92 \mathrm{~kg} \mathrm{P}_{2} \mathrm{O}_{5} \mathrm{ha}^{-1}$ & $32.05 b-f$ & 2.06 & $34.11 b-e$ & $100.16 \mathrm{bc}$ \\
\hline 7 & $111 \mathrm{~kg} \mathrm{~N} \mathrm{ha}^{-1}$ & $28.65 \mathrm{e}-\mathrm{h}$ & 1.68 & $30.33 \mathrm{~d}-\mathrm{g}$ & $94.08 \mathrm{bcd}$ \\
\hline 8 & $111 \mathrm{~kg} \mathrm{~N} \mathrm{ha}^{-1}+46 \mathrm{~kg} \mathrm{P}_{2} \mathrm{O}_{5} \mathrm{ha}^{-1}$ & $33.64 a-e$ & 1.65 & $35.29 a-d$ & $102.84 \mathrm{~b}$ \\
\hline 9 & $111 \mathrm{~kg} \mathrm{~N} \mathrm{ha}^{-1}+92 \mathrm{~kg} \mathrm{P}_{2} \mathrm{O}_{5} \mathrm{ha}^{-1}$ & 34.06a-e & 1.66 & $35.73 a-d$ & $105.5 \mathrm{~b}$ \\
\hline 10 & 5 ton FYM ha ${ }^{-1}$ & $31.85 b-f$ & 1.41 & $33.26 \mathrm{~b}-\mathrm{e}$ & $98.08 \mathrm{bc}$ \\
\hline 11 & 5 ton FYM ha ${ }^{-1}+46 \mathrm{~kg} \mathrm{P}_{2} \mathrm{O}_{5} \mathrm{ha}^{-1}$ & 33.56a-e & 1.86 & $35.42 \mathrm{a}-\mathrm{d}$ & $103.35 b$ \\
\hline 12 & 5 ton FYM ha ${ }^{-1}+92 \mathrm{~kg} \mathrm{P}_{2} \mathrm{O}_{5} \mathrm{ha}^{-1}$ & $33.02 \mathrm{a}-\mathrm{e}$ & 1.86 & $34.89 \mathrm{a}-\mathrm{d}$ & $103.64 b$ \\
\hline 13 & 5 ton FYM ha ${ }^{-1}+46 \mathrm{~kg} \mathrm{~N} \mathrm{ha}^{-1}$ & $34.27 \mathrm{a}-\mathrm{d}$ & 2.08 & $36.36 \mathrm{abc}$ & $98.87 \mathrm{bc}$ \\
\hline 14 & $5 \mathrm{t} \mathrm{FYM} \mathrm{ha}^{-1}+55.5 \mathrm{~kg} \mathrm{~N} \mathrm{ha}^{-1}+46 \mathrm{~kg} \mathrm{P}_{2} \mathrm{O}_{5} \mathrm{ha}^{-1}$ & $35.78 \mathrm{abc}$ & 2.2 & $37.98 \mathrm{ab}$ & $95.83 \mathrm{bcd}$ \\
\hline 15 & $5 \mathrm{t} \mathrm{FYM} \mathrm{ha}^{-1}+55.5 \mathrm{~kg} \mathrm{~N} \mathrm{ha}^{-1}+92 \mathrm{~kg} \mathrm{P}_{2} \mathrm{O}_{5} \mathrm{ha}^{-1}$ & $35.99 \mathrm{abc}$ & 1.91 & $37.91 \mathrm{ab}$ & $94.69 \mathrm{bcd}$ \\
\hline 16 & 5 ton FYM ha ${ }^{-1}+111 \mathrm{~kg} \mathrm{~N} \mathrm{ha}^{-1}$ & $33.32 \mathrm{a}-\mathrm{e}$ & 1.55 & $34.87 \mathrm{a}-\mathrm{d}$ & $96.14 \mathrm{bcd}$ \\
\hline 17 & $5 \mathrm{t} \mathrm{FYM} \mathrm{ha}^{-1}+111 \mathrm{~kg} \mathrm{~N} \mathrm{ha}^{-1}+46 \mathrm{~kg} \mathrm{P}_{2} \mathrm{O}_{5} \mathrm{ha}^{-1}$ & $34.43 a-d$ & 2.25 & $36.68 \mathrm{abc}$ & $98.55 b c$ \\
\hline 18 & $5 \mathrm{t} \mathrm{FYM} \mathrm{ha}^{-1}+111 \mathrm{~kg} \mathrm{~N} \mathrm{ha}^{-1}+92 \mathrm{~kg} \mathrm{P}_{2} \mathrm{O}_{5} \mathrm{ha}^{-1}$ & $36.03 \mathrm{abc}$ & 1.55 & $37.59 \mathrm{ab}$ & $103.05 b$ \\
\hline 19 & $10 \mathrm{t} \mathrm{FYM} \mathrm{ha}^{-1}$ & $30.79 b-f$ & 2.06 & $32.86 \mathrm{~b}-\mathrm{e}$ & $95.54 \mathrm{bcd}$ \\
\hline 20 & $10 \mathrm{t} \mathrm{FYM} \mathrm{ha}^{-1}+46 \mathrm{~kg} \mathrm{P}_{2} \mathrm{O}_{5} \mathrm{ha}^{-1}$ & $30.37 \mathrm{c}-\mathrm{g}$ & 2.44 & $32.81 \mathrm{~b}-\mathrm{e}$ & $95.97 \mathrm{bcd}$ \\
\hline 21 & 10 t FYM ha ${ }^{-1}+92 \mathrm{~kg} \mathrm{P}_{2} \mathrm{O}_{5} \mathrm{ha}^{-1}$ & $34.33 a-d$ & 1.73 & $36.06 \mathrm{abc}$ & $97.66 \mathrm{bc}$ \\
\hline 22 & $10 \mathrm{t} \mathrm{FYM} \mathrm{ha}^{-1}+55.5 \mathrm{~kg} \mathrm{~N} \mathrm{ha}^{-1}$ & $34.57 \mathrm{a}-\mathrm{d}$ & 1.75 & $36.32 \mathrm{abc}$ & $95 b c d$ \\
\hline 23 & $10 \mathrm{tFYM} \mathrm{ha}^{-1}+55.5 \mathrm{~kg} \mathrm{~N} \mathrm{ha}^{-1}+46 \mathrm{~kg} \mathrm{P}_{2} \mathrm{O}_{5} \mathrm{ha}^{-1}$ & $34.94 \mathrm{a}-\mathrm{d}$ & 1.9 & $36.84 \mathrm{abc}$ & $96.09 \mathrm{bcd}$ \\
\hline 24 & $10 \mathrm{t} \mathrm{FYM} \mathrm{ha}^{-1}+55.5 \mathrm{~kg} \mathrm{~N} \mathrm{ha}^{-1}+92 \mathrm{~kg} \mathrm{P}_{2} \mathrm{O}_{5} \mathrm{ha}^{-1}$ & $34.43 \mathrm{a}-\mathrm{d}$ & 2.15 & $36.58 \mathrm{abc}$ & $95.27 \mathrm{bcd}$ \\
\hline 25 & $10 \mathrm{t} \mathrm{FYM} \mathrm{ha}^{-1}+111 \mathrm{~kg} \mathrm{~N} \mathrm{ha}^{-1}$ & $32.39 \mathrm{~b}-\mathrm{f}$ & 1.51 & 33.91b-e & $96.07 \mathrm{bcd}$ \\
\hline 26 & $10 \mathrm{tFYM} \mathrm{ha}^{-1}+111 \mathrm{~kg} \mathrm{~N} \mathrm{ha}^{-1}+46 \mathrm{~kg} \mathrm{P}_{2} \mathrm{O}_{5} \mathrm{ha}^{-1}$ & $36.24 \mathrm{ab}$ & 2.25 & $38.49 \mathrm{ab}$ & $103.4 \mathrm{~b}$ \\
\hline \multirow[t]{3}{*}{27} & 10 t FYM ha ${ }^{-1}+111 \mathrm{~kg} \mathrm{~N} \mathrm{ha}^{-1}+92 \mathrm{~kg} \mathrm{P}_{2} \mathrm{O}_{5} \mathrm{ha}^{-1}$ & $38.65 a$ & 1.48 & $40.13 a$ & $135.03 a$ \\
\hline & CV (\%) & 7.16 & 32.14 & 8.87 & 8.49 \\
\hline & $\operatorname{SEM}( \pm)$ & 7.06 & 0.59 & 2.86 & 2.89 \\
\hline
\end{tabular}

Means with similar letter within a column are not significantly different at 0.05 probability level, DMRT test, Mar = Marketable, Unmar = Unmarketable, $\mathrm{RDF}=$ Recommended dose of fertilizer, $\mathrm{FYM}=$ Farm yard manure, $\mathrm{N}=$ Nitrogen, $\mathrm{P}_{2} \mathrm{O}_{5}=$ phosphorus penta oxide.

\subsubsection{Tuber Yield}

The finding indicated that the main effect of $(\mathrm{N}$ and $\mathrm{P})$ plus organic fertilizer significantly influenced average tuber number at $(\mathrm{p}<0.05)$ on marketable and total tuber yield of Potato. However, it did not differ significantly affect unmarketable tuber yield due to the application of different levels of both organic and 
inorganic fertilizer as well as their interaction.

Application of $\mathrm{N}$ and $\mathrm{P}$ significantly increased total tuber yield and marketable yield of Potato (Table 6). Increasing the level of applied $\mathrm{N}$ from $55.5 \mathrm{~kg} \mathrm{ha}^{-1}$ to $111 \mathrm{~kg} \mathrm{ha}^{-1} \mathrm{~N} \mathrm{ha}^{-1}$ increased total tuber yield from $\left(31.14-35.89 \mathrm{t} \mathrm{ha}^{-1}\right)$ and marketable $\left(29.34-34.16 \mathrm{tha}^{-1}\right)$. In the case of $\mathrm{N}$ where consistent and significant yield increment was observed with increase in the application of the nutrient, increase in the application $\mathrm{N}$ could be attributed to the effect of the nutrient on enhancing leaf growth and leaf surface area. In the same way, increasing $\mathrm{P}_{2} \mathrm{O}_{5}$ application from $46 \mathrm{~kg} \mathrm{ha}^{-1}$ to $92 \mathrm{~kg} \mathrm{P}_{2} \mathrm{O}_{5} \mathrm{ha}^{-1}$ increased total tuber yield (32.17 - $\left.35.54 \mathrm{t} \mathrm{ha}^{-1}\right)$ and marketable tuber yield (30.46 - $\left.33.75 \mathrm{t} \mathrm{ha}^{-1}\right)$. With the increasing rates of FYM from $5 \mathrm{t} \mathrm{ha}^{-1}-10 \mathrm{t} \mathrm{ha}^{-1}$ significantly increased total tuber yield (from $30.07-36 \mathrm{t} \mathrm{ha}^{-1}$ ) as well as marketable tuber yield (from 28.37 - $34.08 \mathrm{t} \mathrm{ha}^{-1}$ ) (Table 6).

Consistently yield-increasing trend was observed with increasing application of farmyard manure, which supports the results of [36] who observed higher potato tuber yield under integrated use of organic (FYM) and inorganic source. This indicated that the application of higher rates of farmyard manure is required to get the highest tuber yield provided that the ease of use of highly decomposed farm yard manure material and other prevailing conditions occur. The present finding is supported by [32], who found that the application of FYM and mineral fertilizers gave a tuber yield increase of $61 \%$, compared with the yield obtained using only mineral fertilizers. Moreover, [37] [38] who indicated that higher yield of crop due to application of FYM was attributed to significantly higher yield components.

The integration of different rates of inorganic fertilizers (NP) with various rates of organic manures (FYM) showed a significant effect on both marketable and total tuber yield; whereas, unmarketable yield was statically not significantly. The application of different rate of inorganic fertilizers such as ( $\mathrm{N}$ and $\mathrm{P}$ ) along with different levels of organic manures FYM significantly increased the marketable tuber and total tuber yield compared with plants that received no treatments.

Total tuber yield also followed in same trend and it was also highest for those treatments which had shown highest marketable yield. This indicate that the application of higher rates of farm yard manure and inorganic fertilizer is required to get the highest tuber yield provided that the availability of organic and inorganic fertilizers. This result agrees with [39] who said that increase in yield of crop might be due to increased dry matter production and its distribution in plant parts.

[40] also reported that the assimilation of dry matter and its distribution within the plant are important processes determining crop productivity. The results of this experiment also confirms the addition of manure increases soil water holding capacity and this means that nutrient would be made available to crops where manure has been added to the soil [41]. 
Average of all treatment indicated that application of the mixture of organic and inorganic fertilizers gave highest total tuber yield as well as marketable tuber yield more over the control. The highest total tuber yield $\left(40.13 \mathrm{t} \mathrm{ha}^{-1}\right)$ and marketable tuber yield $(38.65 \mathrm{t} / \mathrm{ha})$ was recorded with the combined application of $10 \mathrm{t} \mathrm{FYM} \mathrm{ha}{ }^{-1}+111 \mathrm{~kg} \mathrm{~N} \mathrm{ha}^{-1}+92 \mathrm{~kg} \mathrm{P}_{2} \mathrm{O}_{5} \mathrm{ha}^{-1}$ followed by application of $10 \mathrm{t}$ FYM ha ${ }^{-1}+111 \mathrm{~kg} \mathrm{~N} \mathrm{ha}^{-1}+46 \mathrm{~kg} \mathrm{P}_{2} \mathrm{O}_{5} \mathrm{ha}^{-1}$ total tuber yield $\left(38.49 \mathrm{t} \mathrm{ha}^{-1}\right)$ and marketable tuber yield $\left(36.24 \mathrm{t} \mathrm{ha}^{-1}\right)$ which were significantly higher than that obtained marketable tuber yield in the control plot $\left(21.01 \mathrm{t} \mathrm{ha}^{-1}\right)$ (Table 6). This further increase in marketable and total tuber yield of potato with combined application of both of FYM and inorganic fertilizer could be attribute favourable effects on yield components, like average number of tuber per hill, plant height, leaf area and dry matter production.

Similar results were reported by [42] and by [43] who reported that organic manure alone is not sufficient for optimum yield of potato. The integrated use of organic and inorganic fertilizers though influenced the marketable tuber yield to a variable extent but the results of this experiment confirms the observations of [12] who reported that integration of organic and inorganic inputs sustained crop production due to positive interaction and complementarities between them and also agree with the findings of [32] who reported significant increase in tuber yield components with increasing organic manure and inorganic fertilizers which might be due to higher nutrient availability and uptake with higher rates of both fertilizer types and increased availability of plant nutrients [29]. The result clearly revealed that the total yield and marketable yield of potato could be increased by the interaction of organic and inorganic fertilizer.

\subsubsection{Average Tuber Number}

The analysis of result indicated that the main effect of ( $\mathrm{N}$ and $\mathrm{P})$ as well as organic fertilizer significantly influenced average tuber number at $(\mathrm{p}<0.05)$ (Table 5). When application of $\mathrm{N}$ was raised from 55.5 to $111 \mathrm{~kg} \mathrm{~N} \mathrm{ha}^{-1}$ and application of $\mathrm{P}_{2} \mathrm{O}_{5}$ was raised $46-92 \mathrm{~kg} \mathrm{P}_{2} \mathrm{O}_{5} \mathrm{ha}^{-1}$ resulted a significant increase in the average tuber number. Especially average tuber number shows a consistent increasing trend with increasing the level of $\mathrm{N}$ fertilizer. In agreement with the present finding, [44] reported that a significant increases in tuber numbers in response to increased levels of $\mathrm{N}$ application. From my finding observed that the number of tubers varied considerably as a result of $\mathrm{N}$ fertilization, and doubled when $\mathrm{N}$ level was increased to higher levels.

The interaction effects of organic and inorganic fertilizer were significantly different on average tuber number (Table 7). Application of different rate of inorganic fertilizers $\left(\mathrm{N}\right.$ and $\mathrm{P}_{2} \mathrm{O}_{5}$ ) along with different rate of organic manures significantly increased average tuber numbers compared with plants that received no treatments or control. The highest average tuber number (15.53) was recorded with the combined application of $5 \mathrm{t} \mathrm{FYM} \mathrm{ha}^{-1}+55.5 \mathrm{~kg} \mathrm{~N} \mathrm{ha}^{-1}+46 \mathrm{~kg}$ $\mathrm{P}_{2} \mathrm{O}_{5} \mathrm{ha}^{-1}$ followed by application of $10 \mathrm{t} \mathrm{FYM} \mathrm{ha}{ }^{-1}+111 \mathrm{~kg} \mathrm{~N} \mathrm{ha}^{-1}+92 \mathrm{~kg} \mathrm{P}_{2} \mathrm{O}_{5}$ $\mathrm{ha}^{-1}$ total tuber yield (15.4) which were significantly higher than that obtained 
Table 7. Interaction effect of integrated nutrient management on tuber number and average tuber number of potato.

\begin{tabular}{|c|c|c|c|c|c|}
\hline \multirow{2}{*}{ No. } & \multirow{2}{*}{ Treatments } & \multicolumn{3}{|c|}{ Tuber Number } & \multirow{2}{*}{$\begin{array}{c}\text { Ave. Tube } \\
\text { Number }\end{array}$} \\
\hline & & Mark & Unmark & Total & \\
\hline 1 & Control & $290.67 f$ & $30 \mathrm{bc}$ & $320.67 \mathrm{~g}$ & $9.86 \mathrm{i}$ \\
\hline 2 & $46 \mathrm{~kg} \mathrm{P}_{2} \mathrm{O}_{5} \mathrm{ha}^{-1}$ & $301 \mathrm{ef}$ & $28.67 b c$ & $329.67 \mathrm{~g}$ & $10.13 \mathrm{hi}$ \\
\hline 3 & $92 \mathrm{~kg} \mathrm{P}_{2} \mathrm{O}_{5} \mathrm{ha}^{-1}$ & $327.67 \mathrm{c}-\mathrm{f}$ & $30.33 b c$ & $358 \mathrm{fg}$ & $11.93 \mathrm{f}-\mathrm{i}$ \\
\hline 4 & $55.5 \mathrm{~kg} \mathrm{~N} \mathrm{ha}^{-1}$ & $323.67 \mathrm{def}$ & $30.33 b c$ & $354 \mathrm{fg}$ & $11.8 \mathrm{ghi}$ \\
\hline 5 & $55.5 \mathrm{~kg} \mathrm{~N} \mathrm{ha}^{-1}+46 \mathrm{~kg} \mathrm{P}_{2} \mathrm{O}_{5} \mathrm{ha}^{-1}$ & $341.33 \mathrm{c}-\mathrm{f}$ & $33.67 \mathrm{bc}$ & $375 \mathrm{e}-\mathrm{g}$ & $12.5 \mathrm{efg}$ \\
\hline 6 & $55.5 \mathrm{~kg} \mathrm{~N} \mathrm{ha}^{-1}+92 \mathrm{~kg} \mathrm{P}_{2} \mathrm{O}_{5} \mathrm{ha}^{-1}$ & $354.33 b-f$ & $33.67 \mathrm{bc}$ & $388 b-g$ & $12.93 \mathrm{~b}-\mathrm{g}$ \\
\hline 7 & $111 \mathrm{~kg} \mathrm{~N} \mathrm{ha}^{-1}$ & $349.33 b-f$ & $30.67 \mathrm{bc}$ & $380 \mathrm{~d}-\mathrm{g}$ & $12.66 \mathrm{~d}-\mathrm{g}$ \\
\hline 8 & $111 \mathrm{~kg} \mathrm{~N} \mathrm{ha}^{-1}+46 \mathrm{~kg} \mathrm{P}_{2} \mathrm{O}_{5} \mathrm{ha}^{-1}$ & $413.67 \mathrm{ab}$ & $28.33 b c$ & $442 \mathrm{a}-\mathrm{d}$ & 14.73a-e \\
\hline 9 & $111 \mathrm{~kg} \mathrm{~N} \mathrm{ha}^{-1}+92 \mathrm{~kg} \mathrm{P}_{2} \mathrm{O}_{5} \mathrm{ha}^{-1}$ & $424 \mathrm{a}$ & $33 \mathrm{bc}$ & $457 \mathrm{ab}$ & $12.6 \mathrm{~d}-\mathrm{g}$ \\
\hline 10 & 5 ton $\mathrm{FYM} \mathrm{ha}^{-1}$ & $344 c-f$ & $34 \mathrm{bc}$ & $378 \mathrm{~d}-\mathrm{g}$ & $15.23 \mathrm{ab}$ \\
\hline 11 & 5 ton FYM ha ${ }^{-1}+46 \mathrm{~kg} \mathrm{P}_{2} \mathrm{O}_{5} \mathrm{ha}^{-1}$ & $354 b-f$ & $34 \mathrm{bc}$ & $388 b-g$ & $12.93 \mathrm{~b}-\mathrm{g}$ \\
\hline 12 & 5 ton $\mathrm{FYM} \mathrm{ha}^{-1}+92 \mathrm{~kg} \mathrm{P}_{2} \mathrm{O}_{5} \mathrm{ha}^{-1}$ & $387.67 a-d$ & $34.33 \mathrm{bc}$ & $422 \mathrm{a}-\mathrm{f}$ & $14.06 \mathrm{a}-\mathrm{g}$ \\
\hline 13 & 5 ton FYM ha ${ }^{-1}+46 \mathrm{~kg} \mathrm{~N} \mathrm{ha}^{-1}$ & $380.33 a-d$ & $31.66 \mathrm{bc}$ & $412 a-f$ & $13.73 \mathrm{a}-\mathrm{g}$ \\
\hline 14 & 5 t FYM ha $^{-1}+55.5 \mathrm{~kg} \mathrm{~N} \mathrm{ha}^{-1}+46 \mathrm{~kg} \mathrm{P}_{2} \mathrm{O}_{5} \mathrm{ha}^{-1}$ & $430.33 a$ & $35.67 \mathrm{bc}$ & $466 a$ & $15.53 \mathrm{a}$ \\
\hline 15 & 5 t FYM ha $^{-1}+55.5 \mathrm{~kg} \mathrm{~N} \mathrm{ha}^{-1}+92 \mathrm{~kg} \mathrm{P}_{2} \mathrm{O}_{5} \mathrm{ha}^{-1}$ & $417.6 \mathrm{ab}$ & $34.33 \mathrm{bc}$ & $452 \mathrm{abc}$ & $15.06 \mathrm{abc}$ \\
\hline 16 & 5 ton FYM ha ${ }^{-1}+111 \mathrm{~kg} \mathrm{~N} \mathrm{ha}^{-1}$ & $373 a-d$ & $35 \mathrm{bc}$ & $408 \mathrm{a}-\mathrm{f}$ & $13.6 \mathrm{a}-\mathrm{g}$ \\
\hline 17 & $5 \mathrm{t} \mathrm{FYM} \mathrm{ha}^{-1}+111 \mathrm{~kg} \mathrm{~N} \mathrm{ha}^{-1}+46 \mathrm{~kg} \mathrm{P}_{2} \mathrm{O}_{5} \mathrm{ha}^{-1}$ & $384 a-d$ & $36 \mathrm{bc}$ & $420 \mathrm{a}-\mathrm{f}$ & $14 \mathrm{a}-\mathrm{g}$ \\
\hline 18 & $5 \mathrm{t} \mathrm{FYM} \mathrm{ha}^{-1}+111 \mathrm{~kg} \mathrm{Nha}^{-1}+92 \mathrm{~kg} \mathrm{P}_{2} \mathrm{O}_{5} \mathrm{ha}^{-1}$ & $394 \mathrm{abc}$ & $34 \mathrm{bc}$ & $428 \mathrm{a}-\mathrm{e}$ & $14.26 \mathrm{a}-\mathrm{f}$ \\
\hline 19 & $10 \mathrm{t} \mathrm{FYM} \mathrm{ha}^{-1}$ & $351.67 \mathrm{~b}-\mathrm{f}$ & $34.33 \mathrm{bc}$ & $386 \mathrm{~d}-\mathrm{g}$ & $12.86 \mathrm{c}-\mathrm{g}$ \\
\hline 20 & $10 \mathrm{t} \mathrm{FYM} \mathrm{ha}^{-1}+46 \mathrm{~kg} \mathrm{P}_{2} \mathrm{O}_{5} \mathrm{ha}^{-1}$ & $330.33 c-f$ & $34.67 \mathrm{bc}$ & $365 \mathrm{e}-\mathrm{g}$ & $12.16 \mathrm{fgh}$ \\
\hline 21 & $10 \mathrm{t} \mathrm{FYM} \mathrm{ha}^{-1}+92 \mathrm{~kg} \mathrm{P}_{2} \mathrm{O}_{5} \mathrm{ha}^{-1}$ & $385.33 a-d$ & $30.67 \mathrm{bc}$ & $420 \mathrm{a}-\mathrm{f}$ & 13.86a-g \\
\hline 22 & 10 t FYM ha ${ }^{-1}+55.5 \mathrm{~kg} \mathrm{~N} \mathrm{ha}^{-1}$ & $392 a-d$ & $50.67 \mathrm{a}$ & $442.67 \mathrm{ad}$ & $14.86 \mathrm{a}-\mathrm{d}$ \\
\hline 23 & $10 \mathrm{t} \mathrm{FYM} \mathrm{ha}^{-1}+55.5 \mathrm{~kg} \mathrm{~N} \mathrm{ha}^{-1}+46 \mathrm{~kg} \mathrm{P}_{2} \mathrm{O}_{5} \mathrm{ha}^{-1}$ & 364.33a-e & $35.67 \mathrm{bc}$ & $400 \mathrm{a}-\mathrm{f}$ & $13.33 \mathrm{a}-\mathrm{g}$ \\
\hline 24 & $10 \mathrm{t} \mathrm{FYM} \mathrm{ha}^{-1}+55.5 \mathrm{~kg} \mathrm{Nha}^{-1}+92 \mathrm{~kg} \mathrm{P}_{2} \mathrm{O}_{5} \mathrm{ha}^{-1}$ & $412.67 \mathrm{ab}$ & $27.33 c$ & $440 \mathrm{a}-\mathrm{d}$ & $14.66 \mathrm{a}-\mathrm{e}$ \\
\hline 25 & 10 t FYM ha ${ }^{-1}+111 \mathrm{~kg} \mathrm{~N} \mathrm{ha}^{-1}$ & $413 \mathrm{ab}$ & $43.67 \mathrm{ab}$ & $456.67 \mathrm{ab}$ & $15.66 \mathrm{a}$ \\
\hline 26 & 10 t FYM ha ${ }^{-1}+111 \mathrm{~kg} \mathrm{Nha}^{-1}+46 \mathrm{~kg} \mathrm{P}_{2} \mathrm{O}_{5} \mathrm{ha}^{-1}$ & $417.33 \mathrm{ab}$ & $40.67 \mathrm{abc}$ & $458 \mathrm{a}$ & $15.26 \mathrm{ab}$ \\
\hline \multirow[t]{3}{*}{27} & $10 \mathrm{t} \mathrm{FYM} \mathrm{ha}^{-1}+111 \mathrm{~kg} \mathrm{~N} \mathrm{ha}^{-1}+92 \mathrm{~kg} \mathrm{P}_{2} \mathrm{O}_{5} \mathrm{ha}^{-1}$ & $425.33 a$ & $36.67 \mathrm{abc}$ & $462 \mathrm{a}$ & $15.4 \mathrm{a}$ \\
\hline & CV (\%) & 9.32 & 23.25 & 8.57 & 8.72 \\
\hline & $\operatorname{SEM}( \pm)$ & 34.83 & 7.94 & 34.95 & 1.18 \\
\hline
\end{tabular}

Means with similar letter within a column are not significantly different at 0.05 probability level, DMRT test, Mar = Marketable, Unmar = Unmarketable, $\mathrm{RDF}=$ Recommended dose of fertilizer, $\mathrm{FYM}=$ Farm yard manure, $\mathrm{N}=$ Nitrogen, $\mathrm{P}_{2} \mathrm{O}_{5}=$ phosphorus penta oxide.

average tuber number in the control plot (9.8) (Table 7) The current experiment result agree with the findings of [20] the increase in number of average tuber with the combined use of organic and inorganic fertilizer might be due to the increased photosynthetic activity and translocation of photosynthate to the root, which might helped in the initiation of more stolon in potato. Tuber number is 
also determined by the number of stems produced which in turn depends up on the tuber size and variety as reported by [45].

\subsubsection{Marketable, Unmarketable and Total Tuber Number}

Inorganic fertilizer ( $\mathrm{N}$ and $\mathrm{P}$ ) significantly affected the main effect of both marketable and total tuber number; however, there was no significant difference for unmarketable tuber number. On the other hand, and there was significant difference for organic manure on marketable, total tuber number and unmarketable tuber number. The marketable tuber number and total tuber number were continued up to the highest level of the nutrient (10 t FYM ha ${ }^{-1}$ ) (Table 5).

Interaction of organic and inorganic fertilizer significantly influences marketable, total tuber number and unmarketable (Table 7). The lowest total and marketable tuber number was found in the control treatment, suggesting that integrated use of organic and inorganic fertilizer resulted in $5 \mathrm{t} \mathrm{FYM} \mathrm{ha}{ }^{-1}+55.5 \mathrm{~kg}$ $\mathrm{N} \mathrm{ha}^{-1}+46 \mathrm{~kg} \mathrm{P}_{2} \mathrm{O}_{5} \mathrm{ha}^{-1}$ showed higher number of total tubers than control. The finding revealed that in the treatments which had higher marketable tuber number have lower unmarketable tuber number compared with other treatments thus, the minimum marketable tuber number was found in the control. In this experiment, unmarketable tubers numbers refer to unpleasant and underdeveloped tubers (less than $25 \mathrm{~g}$ ). Most of the tubers that were discarded as unmarketable tubers included the ones that were too small in size. The current experiments agree with the finding of [35] who reported the lowest marketable tuber number was obtained in the control treatments.

\section{Conclusion and Recommendation}

Potato (Solanum tuberosum L.) is one of the most important vegetable crops. It is also used as food and cash crop worldwide particularly in Ethiopia. It is successfully produced under rain fed as well as irrigated conditions in different climatic regions of the country for tuber by farmers and commercial growers in Eastern Ethiopia. However, there was no specific fertilizer recommendation for Haramaya areas of potato grower farmers. Overall, based on this study, one could say application of $111 \mathrm{~kg} \mathrm{~N} \mathrm{ha}^{-1}+92 \mathrm{~kg} \mathrm{P}_{2} \mathrm{O}_{5} \mathrm{ha}^{-1}+10$ ton FYM ha ${ }^{-1}$ recommended for smallholder potato producers of Haramaya Woreda of East Hararage Zone and other areas having similar agro ecology and socio-economic environment in the country. But it would be difficult to make definite and widely applicable conclusion based on the research results of only one season and of one site. So that, further studies are needed to better understand its effect on potato production and its economic feasibility.

\section{Acknowledgements}

I express my deepest gratitude and sincere thanks to Dr. Muktar Mohammed and Prof. Nigussie Dechassa for their sustained guidance and support at all stages of the research work. I would also like to thank the Integrated Seed Sector Development Programme (ISSD) of Haramaya University for providing me with 
potato seed tubers, and the Office of Research Affairs of Haramaya University for providing me with material supports during field work. Finally, my heartily thanks goes to my wife Yasmin Mohammed, my sisters Hangatu, Miski, Mahbuba and my brother Ibsa and my friends Fami Abdurhaman, Fuad Abduslam for their encouragement and moral support.

\section{References}

[1] CSA (Central Statistical Agency) (2014) Federal Democratic Republic of Ethiopia, Agricultural Sample Survey Volume I Report on Area and Production Major Crop Statically Bulleting 532. Addis Ababa Ethiopia, 12 p.

[2] FAOSTAT (2010) Agricultural Data Provisional 2007 Production and Production Indices Data. Crop Primary. Food and Agriculture Organization of the United Nations, Rome. http://faostat.fao.org

[3] Gildemacher, P.R., Paul, D., Ian, B., Wachira, K., Gebremedhin, W., Wagoire, W.W., Mercy, W., Cees, L. and Struik, P.C. (2009) A Description of Seed Potato Systems in Kenya, Uganda and Ethiopia. American Journal of Potato Research, 86, 373-382. https://doi.org/10.1007/s12230-009-9092-0

[4] Amede, T., Belachew, T. and Geta, E. (2001) Reversing Degradation of Arable Lands in Ethiopia Highlands. Managing African Soils, Series No. 23. IIED, London.

[5] Ayalew, A. and Dejene, T. (2011) Integrated Application of Compost and Inorganic Fertilizers for Production of Potato (Solanum tuberosum L.) at Angacha and Kokate in Southern Ethiopia. Journal of Biology, Agriculture and Healthcare, 1, 15-24.

[6] Murphy, H.F. (1968) A Report on the Fertility Status of Some Soils of Ethiopia. Experimental Bull. No. 1, Imperial College of Agriculture and Mechanical Arts, Alemaya, $201 \mathrm{p}$.

[7] Gebreselassie, Y. (2002) Selected Chemical and Physical Characteristics of Soils of Adet Research Center and Its Testing Sites in North-Western Ethiopia. Ethiopian Journal of Natural Resources, 4, 199-215.

[8] Anonymous (2004) Directory of Released Crop Varieties and Their Recommended Cultural Practices. Ethiopian Agricultural Research Organization, Addis Ababa.

[9] Tilahun, A., Dechassa, N. and Tana, T. (2015) Response of Potato (Solanum tuberosum L.) Yield and Yield Components to Nitrogen Fertilizer and Planting Density at Haramaya, Eastern Ethiopia. Journal of Plant Sciences, 3, 320-328.

[10] Tsegaye, B., Dachasa, N. and Mohammed, W. (2014) Growth Yield, and Quality Potato (Solanum tubersam L.) Cultivars as Influenced by Plant Spacing at Haramaya and Hirina, Eastern Ethiopia. Msc Thesis, Haramaya University, Haramaya.

[11] Sanchez, P.A. and Jama, B.A. (2000) Soil Fertility Replenishment Takes off in East and Southern Africa. In: Vanlauwe, B., Diels, J., Sanginga, N. and Merckx, Eds., Integrated Plant Nutrient Management in Sub-Saharan Africa: From Concept to Practice, CABI, Wallingford, 23-45.

[12] Vanlauwe, B., Diels, J., Sanginga, N. and Merckx, R. (2002) Integrated Plant Nutrient Management in Sub-Saharan Africa: From Concept to Practice. CABI, Wallingford, 352.

[13] Woomer, P.C., Karanja, N.K. and Okalebo, J.R. (1999) Opportunities for Improving Integrated Nutrient Management by Small Hold Farmers in the Central Highlands of Kenya. African Crop Science Journal, 7, 455-463.

[14] Bonierbale, M., de Hann, S. and Forbes, A. (2006) Procedures for Standard Evalua- 
tion Trials of Advanced Potato Clones: An International Co-Operators' Guide. International Potato Centre (CIP), 124.

[15] Marschner, H. (1995) Mineral Nutrition of Higher Plants. 2nd Edition, Academic Press, London, New York, 889 p.

[16] Brady, N.C. and Weil, R.R. (2002) The Nature and Properties of Soils. 13th Edition, Pearson Education Ltd., London, 156-198.

[17] Hegde, D.M. and Dwivedi, B.S. (1993) Integrated Nutrient Supply and Management as a Strategy to Meet Nutrient Demand. Fertilizer Research, 38, 49-59.

[18] Bwembaya, S. and Yevokun, O.A. (2001) Effects of Cassia spectabilis, Cowdung and Their Combination on Growth and Grain Yield of Maize. 7 th Easter and Southern Africa Regional Maize Conference, Nairobi, 11-15 February 2001, 361-366.

[19] Olani, N. (2002) The Influence of Organic and Inorganic Fertilizer on Herbage and Grain Yield of Two-Grain Sorghum Cultivars. MSc Thesis, Jordan University of Science and Technology, Irbid, $113 \mathrm{p}$.

[20] Annad, S. and Krishnappa, K.S. (1989) Dry Matter Accumulation and Nutrient Uptake by Potato cv. Kufri Badshah as Affected by Deferent Levels of $\mathrm{N}$ and $\mathrm{K}$ in Sandy Loam Soil. Mysore Journal of Agricultural Sciences, 23, 65-70.

[21] Boateng, S.A., Zickermann, J. and Kornahrens, M. (2006) Poultry Manure Effect on Growth and Yield of Maize. West African Journal of Applied Ecology, 9, 1-11.

[22] Shalini, S.B., Channal, H.T., Hebsur, N.S., Dharmatti, P.R. and Sarangamath, P.A. (2002) Effect of Integrated Nitrogen Management on Nutrient Uptake in Knolkhol, Yield and Nutrient Availability in the Soil. Karnataka Journal of Agricultural Sciences, 15, 43-46.

[23] Gonzalez, D.R., Avarez and Matheus, J. (2001) Comparison of Three Organic Fertilizers for the Production of Sweet Corn. Proceedings of the Inter American Society for Tropical Horticulture, 45, 106-109.

[24] Najm, A.A., Haj SeyedHadi, M.R., Fazeli, F., TaghiDarzi, M. and Shamorady, R. (2010) Effect of Utilization of Organic and Inorganic Nitrogen Source on the Potato Shoots Dry Matter, Leaf Area Index and Plant Height, during Middle Stage of Growth. World Academy of Science, Engineering and Technology, 47, 900-902.

[25] Millard, P. and Marshall, B. (1986) Growth, Nitrogen Uptake and Partitioning within the Potatocrop (Solanum tuberosum L.) in Relation to Nitrogen Application. The Journal of Agricultural Science, 107, 421-429. https://doi.org/10.1017/S0021859600087220

[26] Chowdahury, M.R.I., Golam, A.K.M. and Farooque, A.M. (2002) Effect of Different Methods of Urea Application on Growth and Yield in Different Potato. Asian Journal of Plant Sciences, 1, 672-674. https://doi.org/10.3923/ajps.2002.672.674

[27] Olika, A. (2002) Influence of Nitrogen and Phosphorus on Yield, Yield Related and Some Quality Traits of Two Sweet Potato Cultivars. MSc Thesis, School of Graduate Studies of Alemaya University, Alemaya, $124 \mathrm{p}$.

[28] Shaban, K.A. and Omar, M.N.A. (2006) Improvement of Maize Yield and Some Soil Properties by using Nitrogen Mineral and PGPR Group Fertilization in Newly Cultivated Saline Soils. Egyptian Journal of Soil Science, 46, 329-342.

[29] Kundu, S., Bhattacharyya, R., Parkash, V., Ghosh, B.N. and Gupta, H.S. (2007) Carbon Sequestration and Relationship between Carbon Addition and Storage Under Rainfed Soybean-Wheat Rotation in a Sandy Loam Soil of the India Himalayas. Soil \& Tillage Research, 92, 87-95. https://doi.org/10.1016/j.still.2006.01.009

[30] Kotsyuk, V.I. (1995) Using Statistical Methods for Estimating the Effect of Fertiliz- 
ers on Potato Productivity in the Kol'skoi Sybaritic Region. Agrokhinya, 12, 6-88.

[31] Marthin, R.J. (1995) The Effect of Nitrogen Fertilizer on the Recovery of Nitrogen by a Potato Crop. Proceedings Agronomy Society of New Zealand, 25, 97-104.

[32] Taye, M. (2011) Integrated Nutrient Management Studies in Potato. MSc Thesis, Dharwad University of Agricultural Science, Dharwad, 81 p.

[33] Bohlool, B.B., Lindha, J.K., Garrity, D.P. and George, T. (1992) Biological N Fixation for Sustainable Agriculture: A Perspective. Plant and Soil, 141, 1-11. https://doi.org/10.1007/BF00011307

[34] Patricia, I. and Bansal, S.K. (1999) Potassium and Integrated Nutrient Management in Potato. Global Conference on Potato, New Delhi, 6-11 December 1999, 6-11.

[35] Daniel, M. (2007) Effect of Integrated Nutrient Management on Agronomic Performance of Potato and Fertility of Nitosol at Bako. M.Sc. Thesis, Haramaya University, Haramaya.

[36] Sood, M.C. (2007) Integrated Nutrient Supply and Management for Potato Production in Midhills of Shimla. Potato Journal, 34, 101-102.

[37] Jayaprakash, T.C. (2001) Role of Organic and Inorganic in Yield Maximization of Hybrid Maize (Zea mayas L.). M.Sc. Thesis, School of Graduate Studies of Dharward University of Agricultural Sciences, Dharward, $156 \mathrm{p}$.

[38] Sujith, G.M., Ramachandrappa, B.K. and Nanjappa, H.V. (2001) Effect of Irrigation Schedules and Herbicides Application Methods on Growth and Yield of Summer Groundnut. Karnataka Journal of Agricultural Sciences, 14, 610-614.

[39] Kang, B.K. (2004) Effects of Vermicompost on Growth of Fall Cropping Potato in Volcanic Ash Soil. Korean Journal of Crop Science, 49, 305-308.

[40] Tsegaw, T. and Hammes, P.S. (2005) Growth Response of Potato (Solanum tuberosum L.) Grown in a Hot Tropical Lowland to Applied Paclobutrazol: 1. Shoot Attributes, Assimilate Production and Allocation. New Zealand Journal of Crop and Horticultural Science, 33, 35-42. https://doi.org/10.1080/01140671.2005.9514328

[41] Costa, F.C., Hernandez, G.T. and Polo, A. (1991) Residuos Organic Osurbanos in: Manejoy Utilizacion. CSIC, Murrcia, 181.

[42] Shanward, U.K., Agasimani, C.A., Channal, H.T., Palled, Y.B. and Patil, B.C. (2001) Economics of Integrated Nutrient Management in Sunflower Pigeon Pea Intercropping System. Karnataka Journal of Agricultural Sciences, 14, 762-766.

[43] Teklu, E., Stahr, K. and Getachew, T. (2004) Integration of Organic and Inorganic Fertilizers: Effect on Vegetable Productivity. International Research on Food Security, National Resource Management and Rural Development. Humboldt. Univeritatzu, Berlin. http://www.tropentag.de/2004/proceedings/node..html

[44] Sharifi, M., Bernie, J.Z., Mohammad, A.H. and Mahmoud, K. (2005) Dry Matter and Nitrogen Accumulation and Root Morphological Characteristics of Two Clonal Selections of "Russet Norkotah" Potato as Affected by Nitrogen Fertilization. Journal of Plant Nutrition, 28, 2243-2253. https://doi.org/10.1080/01904160500323552

[45] Ebwongu, M., Adipala, E., Ssekabembe, C.K., Yamanywa, S.K. and Bhagsari, A.S. (2001) Effect of Intercropping Maize and Solanum Potato on Yield of the Component Crops in Central Uganda. African Crop Science Journal, 9, 83-96. https://doi.org/10.4314/acsj.v9i1.27628 